\title{
LA VERIFICACIÓN DE PODERES EN LA ELABORACIÓN Y VIGENCIA DE LA CONSTITUCIÓN DE 1812
}

CARMEN FERNÁNDEZ-MIRANDA CAMPOAMOR 


\section{SUMARIO}

1. INTRODUCCIÓN. 2. BREVE APROXIMACIÓN AL ORIGEN DEL CONTROL ELECTORAL PARLAMENTARIO. 3. DEBATE EN TORNO AL ÓRGANO COMPETENTE PARA EJERCER EL CONTROL ELECTORAL EN VÍSPERAS DE LA CONSTITUCIÓN DE LAS CORTES EXTRAORDINARIAS DE 1810. 3.1. Las conclusiones de la Junta de Ceremonial. 3.2. La comunicación de la Comisión de Cortes. 3.3. Actuación del Consejo de Regencia. 3.4. Consideraciones finales. 4. ÁMBITO JURÍDICO DE APLICACIÓN DEL CONTROL ELECTORAL PARLAMENTARIO. 4.1 Ámbito territorial. 4.2. Ámbito material. 5. PROCEDIMIENTO PARLAMENTARIO DE EXAMEN DE ACTAS ELECTORALES. 5.1. Procedimiento inicial. 5.2. El Reglamento provisional de 1810. 5.3. El Reglamento de 1813: primera regulación del procedimiento de verificación de poderes. El Reglamento de 1821 como continuación del anterior. 6. PRÁCTICA PARLAMENTARIA DE LA VERIFICACIÓN DE PODERES. 6.1. Criterios jurídico-políticos aplicados en las Cortes Constituyentes de 1810. 6.2. Criterios jurídico-políticos aplicados en las Cortes de 1813. 6.3. Criterios jurídico-políticos aplicados en las Cortes de 1820. 6.4. Criterios jurídico-políticos aplicados en las Cortes de 1822. 7. FUNDAMENTO Y NATURALEZA DE LA VERIFICACIÓN DE PODERES EN EL PERÍODO 1810-1822. RECAPITULACIÓN. 7.1. Discusión de legitimidades con anterioridad a la constitución de las Cortes de 1810. 7.2 Concepción parlamentaria sobre la verificación de poderes. 


\title{
LA VERIFICACIÓN DE PODERES EN LA ELABORACIÓN Y VIGENCIA DE LA CONSTITUCIÓN DE $1812^{1}$
}

POR

\author{
CARMEN FERNÁNDEZ-MIRANDA CAMPOAMOR
}

UNED

\section{INTRODUCCIÓN}

La verificación de poderes como constatación de que cada uno de los miembros de una Asamblea poseía un mandato regular e inatacable, fue competencia exclusiva del Parlamento en todas nuestras Constituciones históricas. Es la Constitución de 1978 —en su artículo 70.2 — la que judicializa los conflictos de actas electorales, ante el convencimiento de que, en primer lugar, en un régimen constitucional que pretenda someter a derecho todas las relaciones de poder, la decisión sobre la legalidad de las elecciones ha de ser decisión jurisdiccional y no política y, en consecuencia, competencia de los Tribunales de Justicia, como poder del Estado independiente de cualquier influencia. En segundo lugar a que el Parlamento, a lo largo de su historia, ha demostrado cumplidamente su incapacidad, como órgano fundamentalmente político, de tomar una decisión judicial imparcial que garantice a las minorías un tratamiento jurídico adecuado.

Pese al convencimiento teórico aludido, es necesario tener presente que la existencia de un control judicial viable, requiere un sistema político que haga po-

${ }^{1}$ En este artículo vamos a contemplar los días anteriores a la constitución del Congreso extraordinario, la legislatura de 1810 y la posterior aplicación de lo establecido en la Constitución de 1812 y en los correspondientes Reglamentos parlamentarios (1813 y 1821) en las legislaturas de 1813,1820 y 1822. Si interesa un estudio completo sobre esta institución, ver Carmen FERNÁNDEZ-Miranda CAMPOAMOR, La verificación de poderes (1810-1936), UNED 1987. 
sible la incardinación de cada uno de los poderes en un Estado sometido al principio de legalidad; esta carencia, y el consiguiente recelo, no ya español sino continental, ante una organización judicial falta de independencia y, en consecuencia, de representatividad en una labor de creación jurídica, hizo posible el mantenimiento en el Parlamento de una institución que muy pronto se manifestó incapaz de ejercer una adecuada tutela del derecho público subjetivo que corresponde al cuerpo electoral.

La verificación de poderes fue, sin embargo, una institución con un profundo sentido histórico. Su crisis es paralela a la superación de las estructuras políticas del Estado liberal, que se vertebran esencialmente en torno a la quiebra de la soberanía parlamentaria y a la subsiguiente concepción del Parlamento como poder constituido sometido a la Norma fundamental, como un órgano del Estado. Y es en la etapa de elaboración y vigencia de la Constitución de 1812, en la que surgen los criterios que defienden el control electoral como competencia exclusiva del Parlamento. Por tanto, creo imprescindible abordar, no sólo la regulación establecida en la Constitución de 1812 y la práctica parlamentaria derivada de la misma, sino los momentos anteriores a la reunión de Cortes, en donde se plasma de forma directa el duro enfrentamiento entre los partidarios del Antiguo Régimen y los que defienden la instauración de un nuevo sistema político. En este punto, la concepción, y posterior decisión, sobre el titular de la verificación de los poderes, y su contenido, va a resultar determinante.

\section{BREVE APROXIMACIÓN AL ORIGEN DEL CONTROL ELECTORAL PARLAMENTARIO}

Independientemente de la verificación de poderes en los Parlamentos medievales, en los que existía una comprobación de que cada mandatario era realmente el que enviaba el estamento convocado, con un cuaderno de órdenes al que había de someterse taxativamente en su actuación, la verificación de poderes como control del proceso electoral en el régimen representativo español, tiene su origen inmediato en la Francia revolucionaria de 1789, pero su origen mediato en el sistema político inglés del siglo XVII, conocido en el continente a través de Locke y Montesquieu. La interpretación idealista del sistema inglés, hecha por Montesquieu, sirve de base para cimentar el edificio normativo del país vecino, cuya influencia se expanderá por toda Europa, incidiendo directamente en la concepción liberal española de 1810 que, pese a ser minoritaria, dominará las Cortes de Cádiz.

La concentración de poderes propia del Estado moderno, en una de las dos partes de la relación estamental Rex-Regnum, se realizó en distintos sujetos en 
Inglaterra que en el continente europeo ${ }^{2}$. La verificación de poderes corresponderá y será un privilegio propio del titular de ese poder como sujeto jurídico-político de la soberanía estatal: en Inglaterra será asumido por el Parlamento; en el continente por el Rey u organismo dependiente de él y así, en el caso de España, por el Consejo de Castilla, órgano dependiente del Monarca Tema, pues, clave, porque se manifiesta como una consecuencia de la superioridad del órgano que lo posea, y va a ser privilegio discutido y defendido por el Parlamento soberano que surge de la revolución francesa quien, al racionalizar y normativizar la práctica inglesa, se apropia de esa característica peculiar del sistema británico que reconoce a la Cámara de los Comunes la competencia exclusiva de juzgar las elecciones de sus miembros, y la defiende como garantía de su representación e independencia de sus deliberaciones ${ }^{3}$.

El planteamiento que se inicia en España en 1810, recogido en la Constitución de Cádiz, cambia el sentido de una institución existente desde el medievo en dos aspectos: como paso de un mandato imperativo a un mandato representativo, y como poder controlado por la propia Asamblea, en señal inequívoca de superioridad e independencia y cuyo ámbito se extiende al proceso electoral completo.

\section{DEBATE EN TORNO AL ÓRGANO COMPETENTE PARA EJERCER EL CONTROL ELECTORAL, EN VÍSPERAS DE LA CONSTITUCIÓN DE LAS CORTES EXTRAORDINARIAS DE 1810}

El período histórico comprendido entre el levantamiento popular de 1808 y la instalación de las Cortes extraordinarias de 24 de septiembre de 1810, está es-

\footnotetext{
2 M. García-Pelayo, Derecho Constitucional Comparado, Revista de Occidente, Madrid 1959, $5^{a}$ ed., pág. 250. Reeditado por el Centro de Estudios Constitucionales, Madrid 1991

${ }^{3}$ El caso de los Estados Unidos es peculiar. Tanto este nuevo país como Francia realizan la primera aplicación racionalista de la práctica inglesa y ambos países asumen la verificación de poderes para sus asambleas representativas, aunque con muy diferente acento. Estados Unidos es cronológicamente la primera nación que, en su Constitución de 1787 normativiza esta competencia, como propia de una Cámara parlamentaria a quien compete el control del proceso electoral. Asume, pues, una facultad que considera específica de una Asamblea deliberante, pero sin ninguna connotación de bandera defensiva contra un ejecutivo poderoso que, en este joven país, no existe, recién rotas las ataduras históricas con la Inglaterra colonizadora; simplemente, dentro del pragmatismo que le caracteriza, acoge un sistema que considera eficaz. Caso opuesto es el francés, recibido en España, hermanada con él, en que la Cámara defiende aquellos privilegios que le van a dar independencia frente a un ejecutivo absolutista, que no cede voluntariamente ninguna de sus prerrogativas.
} 
tudiado de forma exhaustiva por nuestra doctrina, poniendo de relieve la lucha de legitimidades producida como consecuencia de la desaparición de la estructura de poder absolutista y la absorción de la soberanía abandonada por el pueblo, así como el papel desempeñado por los distintos organismos nacidos al socaire de la quiebra del Antiguo Régimen ${ }^{4}$.

Todo el esfuerzo realizado por la Junta Central durante 1809 para preparar la labor de las futuras Cortes y, en gran medida, encauzar la peligrosa línea innovadora que se presentía, es anulado por el Consejo de Regencia en cuanto asume el poder; actuación que lleva a una situación de improvisación continua, resolviendo los problemas que se van planteando en el último momento y sin ninguna visión de futuro5.

Esto es exactamente lo ocurrido con la verificación de poderes, aparentemente poco importante, pero que va a ser el acento final que determina qué órgano serán las Cortes, ya próximas: si el tradicional apéndice del ejecutivo o un cuerpo legislativo soberano e independiente. Se convierte así en el tema clave de discusión en los días anteriores a la instalación de las Cortes, pues bajo él subyace todo un planteamiento jurídico-político. La lucha ideológica entre el poder tradicionalmente competente para verificar los poderes, el Consejo de Castilla, que reivindica su competencia histórica, y el naciente poder soberano, las Cortes extraordinarias, que lo consideran facultad inherente a su independencia, se pone de manifiesto en algunos documentos ${ }^{6}$, cuyo análisis se someterá a un orden cronológico para mayor claridad y que a continuación se pasa a exponer.

4 Por todos, Miguel ArTola, Los orígenes de la España contemporánea, Tomo I. I.E.P. Madrid 1975, págs. 117 y ss. Derivado de esta controversia surge el problema de quién es competente para convocar Cortes y cuál iba a ser su objetivo. Bien el Consejo de Castilla, convocando unas Cortes tradicionales para organizar la guerra, bien unas Cortes nuevas creadoras de una legalidad distinta

5 Dentro de la trayectoria práctica de la Junta Suprema Central, es necesario señalar la creación de la Comisión de Cortes, organismo constituido para hacer realidad la unánime petición —aunque con distinto acento_- de una próxima reunión de Cortes. Dentro de esta Comisión se crearon cinco Juntas para estudiar cada uno de los temas puntuales que se iban a presentar en las Cortes; entre ellos destaca, a efectos de este estudio, la Junta de Ceremonial de Cortes, creada el 25 de noviembre de 1809 y presidida por Ayamans, teniendo como secretario a Ramírez Cotes. Todas estas Juntas, bajo la inspiración de Jovellanos, tenían como finalidad elaborar, con rigor y perspectiva, todo el plan que habían de estudiar las Cortes Extraordinarias, con el fin de limitar y encauzar la ola revolucionaria, consciente Jovellanos del peligro de reacción ante toda innovación demasiado radical. M. Artola, op. cit. pág. 304. M. Fernández Martín, Derecho Parlamentario Español, Imprenta de de los hijos de J. A. García. Madrid 1885. Documentos.

6 Legajo 5, núm. 18. Expediente sobre el examen de poderes de los diputados a Cortes. Archivo del Congreso de los Diputados (A. C.). Se incluye un interesantísimo escrito del Consejo de Castilla al Consejo de Regencia, fechado el 14 de septiembre de 1810, en el que se hace mención 


\subsection{Las conclusiones de la Junta de Ceremonial}

El único texto legal que determina cómo han de ser los poderes de los diputados y que nada dice sobre el examen de los mismos, es la Instrucción expedida por la Junta Central, sobre las reglas que habrían de observarse para la elección de los diputados a Cortes. De los documentos encontrados en el Archivo se deduce cómo se elaboró esta Instrucción y qué temas soslayó, de momento, la Junta Central.

Dentro de la organización creada por la Central para estudiar todos los problemas relacionados con las futuras Cortes, existe la Comisión de Cortes que, a su vez, trabaja sobre los informes presentados por las diferentes Juntas nombradas para estudiar los temas puntuales. A nuestros efectos interesan las conclusiones acordadas por la Junta de Ceremonial, presentados a la Comisión de Cortes y que ésta, definitivamente, elevará a la Junta Central para que decida. Pues bien, Ramírez Cotes, secretario de la Junta de Ceremonial, firma un escrito fechado en Sevilla el 2 de diciembre de 1809, en el que expone las conclusiones acordadas en la reunión de la última Junta ${ }^{7}$. Estas conclusiones relativas a la naturaleza de los poderes, al examen de los mismos y a la iniciación de las sesiones de las futuras Cotes, son los siguientes.

- Se otorgarán a los diputados unos poderes ilimitados, de forma que estos no queden sujetos a restricciones por parte de ninguna corporación; esto supone el que el diputado no representa a una corporación concreta, a cuyas órdenes taxativas sobre lo que ha de conceder o negar está sometido y ante la que debe responder.

- Los poderes habrán de ser ejercidos por la persona designada para ello, sin que pueda ser sustituida por otra. Este punto indica que la corporación electora no envía a una persona cualquiera, que pueda ser sustituida por otra, dado que lo importante son las órdenes a cumplir y no quién las cumpla. Es decir, se pone el acento en la persona que recibe el mandato y no en el contenido del mismo, pues este contenido deja de ser concreto para convertirse en abstracto.

- Los poderes habrán de ser uniformes. Esta exigencia contempla la igualación de los diputados, ya que dejan de ser representantes de una corporación determinada que da «sus órdenes» distintas, lógicamente, a las de las demás.

de antecedentes y reflexiones sobre la verificación de poderes de los diputados, reivindicando su competencia, que nos ha permitido reconstruir los acontecimientos acaecidos desde el 22 de diciembre de 1809 hasta el 14 de septiembre de 1810 .

7 Incluido en el documento citado anteriormente (nota 6). 
Los tres puntos comentados establecen la ruptura con el mandato imperativo, propio del Antiguo Régimen, dando paso a un mandato representativo, acorde con la nueva legalidad que se quiere instaurar. Pero las conclusiones de la Junta se refieren también a lo que llaman «una comisión de tanta confianza que ejerza la función de examinar los respectivos poderes de los diputados», examen que se realizará de la siguiente forma.

En primer lugar, el Presidente de la Junta Suprema convocará a los diputados que hayan llegado uno de los días anteriores a la instalación de las Cortes, para que éstos nombren habilitadores en el número que crean oportuno, a fin de examinar los respectivos poderes de los diputados, aprobándolos si se adaptan al Reglamento. Este punto encierra un gran contenido. Por un lado significa el abandono del sistema tradicional de reconocimiento de los poderes a cargo del Consejo de Castilla, competencia absorbida por las propias Cortes. Sin embargo, aún no se ha roto totalmente la dependencia del legislativo con el gobierno de la nación, puesto que en este acto interviene el Presidente de la Junta Central, aunque sólo a efectos de convocar y presidir, puesto que el nombramiento y el número de habilitadores lo decidirán los mismos diputados. Por otro lado, este examen de los poderes supera el mero reconocimiento ${ }^{8}$, pues exige la calificación de que se adapten a la reglamentación pertinente.

En segundo lugar, si lo poderes fueran defectuosos, estos habilitadores presentarán a las Cortes un dictamen, para que éstas resuelvan. Por tanto, esa comisión formada por los habilitadores aprobará los poderes correctos pero, ante aquellos que no sean, elevará a las Cortes un dictamen, para que éstas decidan. Antes de ejercer tal cometido, los habilitadores habrán de prestar un juramento de imparcialidad y respeto a la ley, ante el Presidente de la Junta Suprema. Su misión, pues, está considerada como una función judicial, sin mencionar este término, que exige al juzgador que se adapte a la ley, «servir fiel y legalmente su empleo»; de una forma imparcial, «sin separarse jamás de lo justo por respeto alguno, ni inclinarse a favor de nadie por causa de amistad, parentesco ni otro motivo». Conviene precisar que el Consejo de Castilla, en su función de reconocer los poderes de los procuradores, actuaba como un tribunal administrativo de justicia ${ }^{9}$, y con esas mismas características se concibe la nueva atribución.

En tercer lugar, bastará con la presencia de más de la mitad de los diputados para comenzar el funcionamiento de las Cortes. La exigencia responde a la nece-

8 Término usado al hablar del sistema tradicional del mandato imperativo; los partidarios de la nueva representación utilizan la palabra «examen».

9 «Tribunal recto e imparcial, que merece la mayor opinión de los pueblos», en Documento citado en nota 6. 
sidad de apresurar la instalación de aquéllas ya que, pese a las previsiones legales que se pudiesen hacer, dada la dificilísima situación bélica del país, se veía ya como imposible el que todas las elecciones se realizasen en la fecha prevista y que todos los diputados estuviesen presentes en el momento de la apertura de las sesiones. Esta preocupación enlaza con la sentida respecto al diputado que no estuviese presente, el cual no podría reclamar contra lo acordado durante su ausencia.; más que una declaración formal de cosa juzgada, este valor de inapelables dadas a las decisiones de la Cámara, parece responder al intento de dar una cierta estabilidad y coherencia a un órgano que va a empezar a funcionar en circunstancias extraordinarias.

Sobre estas conclusiones de la Junta de Ceremonial trabajará la Comisión de Cortes, elaborando un comunicado que presenta a la Junta Central el 8 de noviembre de 1809, junto al Proyecto de Instrucción sobre las reglas que habrán de observarse para la elección de diputados.

\subsection{La comunicación de la Comisión de Cortes}

El trabajo de la Comisión de Cortes, firmado por Jovellanos, Martín de Garay y Ayamans, recoge las sugerencias de la Junta de Ceremonial, incluyendo las relativas a los poderes en el Proyecto de Instrucción y expresando las concernientes al examen de poderes en una comunicación aneja ${ }^{10}$, que quedó en papel mojado, pues la Junta Central no decidió nada al respecto, dada la discusión de competencias existente sobre el ejercicio de tal función. Esta comunicación se refiere a los siguientes aspectos.

Como punto de partida las Cortes, en el primer día de su funcionamiento, nombrarán un cierto número de habilitadores. Por tanto, mantiene la idea de la Junta de Ceremonial de que se nombre tal comisión por los propios diputados, dejando el número a su discreción; al exigir que ese nombramiento se haga ya instaladas las Cortes, elimina la intervención del Presidente de la Junta Central, transfiriendo la competencia totalmente al nuevo cuerpo ${ }^{11}$. Esto supone la declaración de independencia del legislativo en una de sus funciones claves, como es la de constituirse.

10 Fernández Martín, Documentos, op. cit., pág. 574.

11 La comunicación de la Comisión de Cortes no se conoció públicamente, pero sí las conclusiones de la Junta de Ceremonial, debido al escrito publicado por su secretario, RAmírez CoTES, que será utilizado como argumento por algunos diputados para atacar la competencia del Consejo de Castilla en la verificación de poderes, intentando presionar al Consejo de Regencia para que decidiese en su favor. 
Esta comisión examinará y aprobará los poderes si se adaptan a las reglas determinadas por la Instrucción. Supone este punto un paso más, también, respecto a las conclusiones de la Junta de Ceremonial ya expuestas, puesto que exige la adaptación de los poderes a una ley concreta, la Instrucción; como ésta determina que el diputado electo reúna unos requisitos de capacidad y que su elección cumpla las solemnidades previstas y no haya sido realizada bajo cohecho o soborno, el contenido del examen se enriquece, consistiendo en analizar si el electo es capaz y si su elección se ha realizado legalmente. En el caso de que la elección examinada no reúna los requisitos exigidos, la comisión elevará un dictamen a las Cortes, cuerpo que decidirá en última instancia. Se mantiene, pues, la idea de la Junta de Ceremonial, tanto en el aspecto de que en caso de conflicto deciden las Cortes, como en el de considerar inapelable su decisión, pues también priva a los diputados que no estuvieran presentes, del derecho a recurrir lo acordado. Respecto al número de diputados necesario para comenzar el funcionamiento del nuevo cuerpo, la Comisión utiliza un vocablo más ambiguo que la Junta de Ceremonial; ésta exigía la presencia de la mitad de los diputados; aquélla pide que estén presentes la «mayor parte». La petición responde, en ambos casos, a iguales motivos: según se va acercando el momento, se ve más claramente la imposibilidad de reunir, ni siquiera, un número aceptable.

Por último, la Comisión de Cortes elimina el requisito de prestar un juramento ante el Presidente de la Junta Central, como si la comisión fuese un tribunal de justicia nombrado por el rey. Rompe con la concepción anterior de forma que los diputados, previa admisión, jurarán ante las propias Cortes.

A través de estas elaboraciones de la Junta de Ceremonial y de la Comisión de Cortes, los conceptos de soberanía nacional y de división de poderes, conceptos que se manifiestan posteriormente, ya instaladas las Cortes, subyacen en todas las expresiones. Aunque estos acuerdos no se publicaron, fueron ineficaces sólo aparentemente, pues comenzadas las sesiones del Congreso se llevarán a la práctica. Es preciso analizar a qué es debido el que, presentado por la Comisión de Cortes a la Junta Central, un trabajo elaborado que abarcaba tanto la reglamentación del proceso electoral como la naturaleza jurídica de los poderes y el examen de los mismos, esta Junta Central en la Instrucción de 1 de enero de 1810 aborda los dos primeros temas, pero no el relativo a la verificación de poderes, problema con el que se iban a encontrar los diputados en la primera sesión que tuviesen.

En la mencionada Instrucción se determina claramente la fórmula de los poderes que han de traer los diputados a Cortes, fórmula que supone la ruptura con la tradicional concepción estamental del mandato imperativo, según la cual una determinada corporación enviaba a las Cortes un representante suyo, con 
unas órdenes concretas y taxativas, a las cuales había de acomodarse y de cuyo cumplimiento respondía. La nueva regulación, en la línea seguida por los aludidos organismos preparadores, regula el otorgamiento de unos poderes personales, uniformes e ilimitados, propios de la nueva concepción política ${ }^{12}$. Es decir, oficialmente se plasman en un texto legal las ideas relativas a un mandato diferente, en el que los diputados representan a la nación entera, término éste que, aunque no se formule, está implícito en la regulación.

Por tanto, la Junta Central no tuvo problema para regular en la Instrucción la novedad jurídica relativa a la calidad de los poderes; sin embargo hubo de obviar el tema relativo al control de los mismos, detrás del cual estaba la concepción involucionista del Consejo de Castilla. La Junta Central, en vísperas tensas de ser sustituida por el Consejo de Regencia, no tiene la fuerza inicial y no se atreve a enfrentarse abiertamente al Consejo de Castilla, cuya postura aferrada a la legitimidad anterior conocía, pues consta ${ }^{13}$ que, con posterioridad a recibir, el 8 de noviembre de 1809, las opiniones de la Comisión de Cortes, conoce un escrito de aquel organismo en el que reivindica su competencia histórica a reconocer los poderes.

Los hechos sucedieron así: el Consejo de Castilla se reúne en pleno al llegar a sus manos «un papel impreso atribuido a Lord Holland» ${ }^{14}$ en contra de la práctica histórica; el alto organismo se opone a las nuevas ideas y envía sus conclusiones, el 22 de diciembre de 1809, a la Junta Central, apoyándose en los siguientes argumentos: el Consejo de Castilla debe seguir reconociendo los poderes «porque así se ha ejecutado (...) sin que en este punto (...) se haya hecho alteración a lo menos de algunos siglos a esta parte». Es decir, considera como bueno lo que es tradicional y rutinario, argumento típico reaccionario con el que siempre se enfrentó Jovellanos ${ }^{15}$. Por otro lado, se opone al aludido escrito de Lord Holland basándose fundamentalmente en que no es fácil evitar el error cuando se

12 Fernández Martín, obra citada, pág. 574: «Les otorgan poderes ilimitados a todos juntos y cada uno de por sí, para (...) acordar cuanto se proponga en las Cortes». Es necesario resaltar como los mandatarios son llamados tradicionalmente procuradores y diputados a partir de la nueva regulación

13 En el documento citado anteriormente, en nota 6.

14 Amigo personal de Jovellanos, con el que mantiene una larga correspondencia sobre los temas del momento. También tuvo amistad con Argüelles, con motivo de su estancia en Londres en 1806. Argüelles, A. La reforma constitucional de Cádiz. Ed. Iter, Madrid 1970 (comentado por Jesús Longares)

15 Así en Discurso dirigido a la Real Sociedad de Amigos del país de Asturias... B.A.E, T. L, pág. 489.6 «la preocupación, inseparable compañera (de la ignorancia) levanta a todas horas el grito contra toda novedad, sin examinar si es útil, y declama continuamente que sean erróneas y funestas. Ambas prefieren el mal conocido que el bien por conocer (...)». 
habla de un país extraño. Califica tal escrito de "paralogismos subversivos», atacando las ideas que expone. Respecto a que han de ser los propios diputados los que deben examinar los poderes, el Consejo de Castilla considera que este reconocimiento no deben hacerlo los mismos apoderados ${ }^{16}$, que serían jueces y partes $^{17}$, sino $«(. .$.$) un Tribunal de Justicia recto, imparcial (...) el primero del reino$ (...) cuyo gobierno le está encomendado»; es decir, el Consejo de Castilla como tribunal y gobierno, frente a un planteamiento novedoso basado en la separación de poderes. Ante el argumento de la ineficacia de su control, responde que no ha sido debido a falta de capacidad sino al despotismo ministerial, no estando el remedio en privarle de sus competencias sino en afianzar su independencia y vigor $^{18}$. Alega que así como en el transcurso de la historia han abundado las peticiones de que los Reyes no interviniesen en el nombramiento de los procuradores $^{19}$, nunca hubo reclamación alguna sobre el reconocimiento de los poderes. Por último, defiende su derecho basándose en que la experiencia de siglos es la mejor maestra, no pudiendo saberlo aquél que «no está versado en los (negocios) de España»; con una simpleza admirable rechaza la posible influencia inglesa en las instituciones españolas, en una intransigencia de siglos hacia lo extranjero.

En este escrito se encuentra la razón de que la Junta Central no decidiese nada sobre la verificación de poderes; en consecuencia, publica la Instrucción de 1 de enero de 1810 recogiendo todas las sugerencias de la Comisión de Cortes

16 Son de destacar los términos que utiliza el Consejo de Castilla a diferencia de los partidarios del nuevo planteamiento: «reconocer», «apoderado», «procuradores», frente a «examinar», «representantes», «diputados», que usan los liberales.

17 Es muy curioso que este argumento, reaccionario en este momento en que prima fundamentalmente la defensa de la soberanía del Parlamento, va a volver a tener fuerza a finales del siglo XIX de la mano de los defensores del Estado de derecho, hechas las salvedades de concepción necesarias: tribunal dependiente del Rey/tribunales independientes, como otro poder del Estado

18 «(...) sean sus personas inviolables del predominio de los malvados y de los tiros de la envidia; no se les puede despojar de sus empleos sin ser juzgados públicamente por el mismo tribunal o por el que se determina por ley hecha en Cortes; quítese las trabas y embarazos que han entorpecido la justicia y han dexado libre el curso de las pasiones y a los escándalos; sean elegidos sus individuos por un orden gradual, precediendo las consultas de la Cámara; y V. M. notará la independencia, la firmeza, el vigor y la rectitud del Consejo (...)».

19 El derecho de las comunidades o concejos de elegir procuradores a Cortes fue conculcado numerosas veces por los Reyes, quienes decidieron en varias ocasiones quiénes habían de ser procuradores; las ciudades intentan defenderse contra la imposición real (Sentencia de Medina del Campo, 1465). En Martínez Marina, F. Teoría de las Cortes, Tomo I. Editora Nacional, Madrid 1979, pág. 363. Los documentos aportados por este autor en su estudio sobre las Cortes tradicionales demuestran, efectivamente, que la conflictividad se centraba en la intervención del Rey y no en el reconocimiento de los poderes. 
menos las relativas a este tema, que se perfila como base de una u otra concepción jurídico-política. La Junta Central no tiene fuerza ya para imponer la línea innovadora que había iniciado al comienzo de su andadura.

\subsection{Actuación del Consejo de Regencia}

El 30 de enero de 1810 asume todos los poderes un Consejo de Regencia que va a sustituir a la disuelta Junta Central y que será el órgano que habrá de tomar una decisión sobre la constitución de las futuras Cortes, el 14 de septiembre de 1810. Sin embargo, la génesis de esta decisión no es diáfana sino tortuosa y ambigua. Uno de los primeros pasos dados por este organismo y, mencionado repetidamente, fue destituir a la Comisión de Cortes, olvidando su línea innovadora y retomando un camino de defensa de la legitimidad tradicional. Esta afirmación se basa en las disposiciones que a continuación se señalan ${ }^{20}$.

El 15 de agosto de 1810, el Consejo de Regencia expide una Real Orden por la que se reconoce al Consejo de Castilla como el órgano competente para llevar a cabo el examen de los poderes, ya que manda que ante este Tribunal exhiban sus poderes los diputados ${ }^{21}$. Se expiden órdenes en igual sentido, con motivo de la convocatoria de emigrados de las provincias y en relación a los diputados americanos. Igualmente, el Consejo de Regencia nombra a dos secretarios de la Cámara de Castilla para que lleven a efecto la función señalada ${ }^{22}$.

Frente a esta línea de conducta seguida por el organismo, consta que algunos diputados de Cortes, ya llegados a Cádiz, debido a las conclusiones que había elaborado la antigua Junta de Ceremonial, manifiestan al Consejo de Regencia su intención de recurrir la competencia de la Cámara de Castilla sobre el examen de poderes $^{23}$. Con este motivo el Consejo de Regencia acude en consulta al de Castilla el 11 de septiembre de 1810, enviándole el escrito de Ramírez Cotes que da a luz las conclusiones de la Junta de Ceremonial, y pidiendo al alto organismo su

$20 \mathrm{Y}$ que constan en el documento citado en nota 6.

21 El Consejo de Regencia utiliza de forma desordenada los términos examen, reconocimiento, diputados y procuradores; incluso juntos los de «reconocimiento y examen de poderes; el motivo, más que una razón de contenido ideológico, parece ser la línea ambigua que mantuvo el organismo en todas sus actuaciones.

22 Decreto del Consejo de Regencia por el que se nombra para «el examen de los poderes de los Procuradores a Cortes a los dos Secretarios del Consejo y Cámara don Esteban Varea y don Silvestre Collar», 24 de agosto de 1810. En documento citado en nota 6.

23 Ibídem. Por palabras del propio Consejo de Regencia: «Habiendo llegado a oídos de la Regencia que algunos de los Diputados a Cortes pensaban en representar contra la costumbre de que la Cámara reconozca los poderes de los procuradores $(. .)$.$» .$ 
opinión ${ }^{24}$. La contestación del Consejo de Castilla no se hace esperar; el 14 de septiembre envía al Consejo de Regencia un largo Dictamen, ratificándose en su criterio de ser el único órgano competente y adecuado para ejercer la discutida función ${ }^{25}$.

El dictamen hace referencia a los siguientes puntos: en primer lugar, menciona la opinión del pleno del Consejo de Castilla expuesta a la Junta Suprema el 22 de diciembre de 1809, considerando que si este organismo la hubiera llevado a la práctica en vez de solicitar opiniones, en su consulta al país, se hubiera evitado muchos males ${ }^{26}$. Considera que la opinión manifestada en aquel momento, tenía su base legal en la «Colección de memorias y noticias del gobierno general y política del R. y Supremo Consejo de Castilla», que atribuye a este organismo el reconocimiento de los poderes ${ }^{27}$. En segundo lugar, defiende la continuidad de su competencia al considerar que no hay un Tribunal más respetable que el de la Cámara de Castilla, porque sus componentes son «ministros colaterales del Soberano». Este argumento es justo el que utilizan los revolucionarios para desechar la intervención del Consejo de Castilla, ya que pretenden aislar a las nuevas Cortes de la ingerencia de todo poder extraño a ellas. Son dos planteamientos divergentes que no pueden entenderse. En tercer lugar, el Consejo de Castilla manifiesta que, hasta el momento no recibió ninguna reclamación, despachando el citado escrito de Ramírez Cotes remitido por el Consejo de Regencia, con un «no merece nos detengamos en impugnarlo». En cuarto lugar, se ratifica en su opinión de que no pueden ser jueces y partes los mismos procuradores, calificándolo de incongruencia. Por último la revocación de las R. Órdenes por las que el Consejo de Regencia atribuye a la Cámara de Castilla esta prerrogativa, supondría «demasiada condescendencia en prejuicio de su autoridad y prudente fortaleza». Por tanto, el dictamen emitido por la Cámara de Castilla el 14 de septiembre de 1810 no puede ser más tajante.

24 Ibidem.

25 Ibidem. Dictamen que ha sido utilizado para reconstruir todo el período. Documento citado en nota 6.

26 «(...) provocando de este modo la novedad y excitando a muchos arto satisfechos que con poca o ninguna lectura de nuestras antigüedades se han dedicado a la peligrosa de libros extranjeros $(\ldots) »$

27 Documento citado en nota 6. En la pág. 38, dice: «(...) si S. M. manda convocar las Cortes se comunica la Real Orden al señor Presidente o Gobernador y a los dos señores Ministros del Consejo de la Cámara que nombra para reconocer los poderes (...)». Igualmente se refiere esta «Colección de memorias (...)» en el capítulo 57, «con mayor extensión a las reglas que debe observar la Cámara de Castilla cuando el Rey convoque Cortes generales, tanto para la jura de Príncipes como para otros asuntos útiles al Reyno, en relación a la presentación y juramento de los procuradores, a sus poderes, al reconocimiento de éstos y a la apertura de sesiones (...)». 
Con lo hasta aquí reseñado, se ve claramente cómo las dos concepciones existentes son radicalmente antagónicas e imposibles de enlazar. Por un lado, el Consejo de Castilla, desde su competencia histórica, enclavada en el antiguo régimen y concibiendo las Cortes como un organismo dependiente del Rey; por otro, los diputados liberales, apoyados en los trabajos elaborados por la Junta de Ceremonial y la Comisión de Cortes, partiendo de una separación de los poderes del Estado y pergeñando un legislativo aislado de la influencia de cualquier órgano y al que, en consecuencia, corresponde decidir sobre su propia constitución y sus propios componentes. La decisión final que ha de tomar el Consejo de Regencia, no es fácil y en la Real Orden de 14 de septiembre de $1810^{28}$, intentando contentar a $\operatorname{todos}^{29}$, adopta una curiosa vía intermedia apoyándose en las circunstancias extraordinarias que concurren.

El texto legal sugiere los siguientes comentarios: el Consejo de Regencia acepta el que ha habido una elaboración de la Comisión de Cortes, elevada en su día a la Junta Central, sobre la que nada se decidió. Es decir, que las pretensiones de algunos diputados de recurrir contra la competencia del Consejo de Castilla tiene una base real; al mismo tiempo reconoce oficialmente que las Cortes que van a comenzar son extraordinarias ${ }^{30}$. Como «regalía» califica tal función y en tal sentido el Rey es su único titular, por lo que, sin privar al Consejo de Castilla de su ejercicio histórico como supremo órgano administrativo, en las presentes circunstancias especiales y solamente para ellas, se lo atribuye personalmente el Consejo de Regencia como legítimo representante del Rey. Concluye que, debido a sus múltiples ocupaciones, solamente examinará y aprobará los poderes de seis procuradores ${ }^{31}$, delegando su competencia en estos seis individuos, que exa-

28 Publicada en la Gaceta extraordinaria de la Regencia de España e Indias, de 16 de septiembre de 1810, núm. 68, págs. 675-676, A. C.

29 En A. C. existen varios borradores sobre esta Real Orden en los que se puede observar cómo se van perfilando los términos empleados. Incluidos en el expediente del Legajo 5, núm. 18.

30 En los borradores aludidos se lee lo siguiente: «(...) siendo las que ban a celebrarse generales, extraordinarias y muy diversas de las antiguas y posteriores, por lo cual parece que todo exige un nuevo sistema y reglas (...)». En la redacción última se suprime este reconocimiento tan amplio para decir simplemente que «(...) estas Cortes generales son extraordinarias (...)». Se puede observar la alusión a que estas Cortes son diferentes a las anteriores y posteriores; parece, pues, que el Consejo de Regencia no se plantea un cambio definitivo, sino sólo para el momento presente.

31 Utiliza indistintamente los términos tradicionales y nuevos. Los seis procuradores cuyos poderes examinará y aprobará el Consejo de Regencia son: don Benito Ramón Hermida (Reino de Galicia); Marqués de Villafranca (Reino de Murcia); don Felipe Amat (Principado de Cataluña); don Antonio Oliveros (Provincia de Extremadura); don Antonio Samper (Reino de Valencia), y don Ramón Power (Isla de Puerto Rico). Se elige a Hermida y él da los nombres de los otros, probablemente sin conocer a fondo sus ideas. Hermida, alto funcionario del Antiguo Régimen, ideas 
minarán los poderes del resto. Es decir, les concede una delegación momentánea de un ejercicio que, en definitiva, sigue perteneciendo al Consejo de Castilla. La solución no puede ser más ambigua, ni se rompe con el pasado ni se regula definitivamente el futuro, sino que se opta por una vía intermedia, intentando evitar enfrentamientos y dejando en manos de la parte más organizada la nota final.

A partir, por tanto, del 14 de septiembre de 1810, la prerrogativa de la verificación de poderes se la atribuye el Consejo de Regencia, quien la delega provisionalmente en una junta de diputados nombrada por él; así, esta junta no ejerce una facultad propia sino una delegación expresa de una competencia perteneciente al órgano de gobierno que representa al Rey. Aún sigue el planteamiento tradicional. Prueba de esto es el acuerdo tomado por la junta de diputados sobre su falta de competencia para solucionar determinados problemas, cediendo la última decisión al Consejo de Regencia como auténtico titular ${ }^{32}$. De momento, pues, la Real Orden del Consejo de Regencia decide la titularidad de la verificación,; sin embargo esta solución no es aceptada de forma unánime, ya que tres diputados de Extremadura presentan a la junta de examen un memorial reivindicando para las Cortes el examen de los poderes de sus miembros ${ }^{33}$.

Ya en la práctica, y según la vía adoptada por el Consejo de Regencia, este organismo examina los poderes de los diputados nombrados ${ }^{34}$, siendo aprobados todos menos los de don Antonio Samper, por no haberlos recibido, con lo que la junta inicial quedó reducida a cinco componentes. Esta junta será auxiliada por uno de los secretarios del Rey ${ }^{35}$; luego, aunque la formen cinco diputados, actúa

ilustradas; Amat, Caballero del Hábito de San Juan, conservador; Villafranca, Militar, liberal; Power, Militar, liberal; Oliveros, Presbítero, liberal radical. En Martínez Quintero, Grupos liberales antes de Cádiz, Ed. Narcea, Madrid 1977, pág. 260

32 Acuerdo de la Junta de Diputados: «Habiendo visto igualmente una representación de don Guillermo Huarte (...) fecha 18 de septiembre de 1810 (...) comisionado de la Junta Superior de Cuenca en que manifestando hallarse nombrado diputado de aquella provincia don Manuel Rojas Cortés, oficial de la Secretaría del Despacho de Hacienda, cuyos poderes traen otros diputados, que por falta de buque seguro no ha llegado todavía, para que respecto a no poderse dudar de su elección (...) se le reconozca por legítimo diputado y se le admita como a los demás, que han presentado poderes admitiéndose igualmente a (ilegible) primer suplente elegido por la misma provincia, en lugar del diputado don Fernando Casado que se halla en manos de los franceses en el Puerto de Santa María; dijeron NO TIENEN FACULTADES PARA RESOLVER Y QUE ESTE INTERESADO ACUDA AL CONSEJO DE REGENCIA SI LE CONVIENE». A. C. legajo 7 , núm. 25.

33 A. C. legajo 7 , núm. 25.

${ }^{34}$ Nombramiento: «(...) se citará a estos señores para el 14 a las doce». Aprobación de estos poderes certificada el día 15. En expediente del legajo 5, núm. 18. A. C.

35 «(...) se acordó que entre tanto los cinco señores restantes evacuasen la comisión puesta a su cuidado, nombrando de los secretarios del Rey el que tuviesen por conveniente, y, reunidos in- 
como secretario de la misma alguien ajeno al Parlamento, aunque nombrado por los diputados. El motivo pudiera ser el mantener dentro de esta función a alguna persona perteneciente al gobierno de la nación, puesto que el derecho de verificación no se había trasladado a los diputados sino que, perteneciendo al Consejo de Regencia, se delegaba en ellos. Otro dato que parece avalar esta idea es el que el sitio de reunión de esta junta va a ser el propio palacio en el que está instalada la Regencia; ahí habrán de acudir los diputados que van llegando a presentar sus poderes.

\subsection{Consideraciones finales}

A través del estudio realizado se observa la existencia de fuertes presiones en torno a las decisiones que ha de tomar el Consejo de Regencia sobre la constitución de las futuras Cortes extraordinarias. En consecuencia, sus previsiones son exactamente la falta de previsiones, siendo conscientes de la provisionalidad de sus medidas y de su falta de autoridad. Justifica esta apreciación el hecho de que el Consejo de Regencia, por iniciativa propia, traslada a la junta de diputados una de las competencias más importantes para un cuerpo deliberante, como es la redacción de su propio Reglamento ${ }^{36}$; es curioso constatar los términos de respeto y alabanza con que se dirige a los mandatarios, confirmación clara del protagonismo que estos van logrando en detrimento de la autoridad del órgano titular de la soberanía hasta el momento. Este encargo fue rechazado, alegándose la divergencia de planteamientos entre uno y otros ${ }^{37}$, pero en realidad por no querer fijar a priori los temas a tratar, dejando al nuevo cuerpo deliberante en libertad total.

mediatamente en una de las salas del Real Palacio de la Aduana, frente de la que el Supremo Consejo de Regencia tiene su despacho ordinario, y en la que esta nueva junta continuará diariamente sus sesiones a las diez de la mañana, nombraron por su secretario al de S. M. don Tadeo Francisco Calomarde (...)». Gaceta extraordinaria de la Regencia, 16 de septiembre de 1810, núm. 68. A. C.

36 Escrito dirigido a don Ramón Hermida, como Presidente de esa Junta de Diputados: «Excmo Señor, justamente persuadido el Consejo de Regencia de los sublimes comienzos de esa Comisión, ha creído que ninguno le ilustraba más bien de los puntos que debería tratarse en las primeras sesiones del augusto congreso de las Cortes y, al fin de proponerlos con oportunidad, ha resuelto y encarga a V. E. que, con los demás individuos y otra comisión, forme y remita a la posible brevedad un Reglamento comprensible de los insinuados puntos» (fechado el 18 de septiembre de 1810). A. C. Legajo 7 núm. 25.

37 «Aquéllas (Cortes) limitadas a la esfera de un Congreso Nacional del Soberano y éstas elevadas a las de un soberano Congreso, cuyo nombre es el que legítimamente le corresponde más que el equívoco de Cortes (...)», en M. Fernández Martín, op. cit., Documentos, pág. 704. 
En consecuencia, la Regencia que desde el inicio de su mandato obvió todos los estudios realizados por la Comisión de Cortes, dirigida por Jovellanos, limita su actuación al envío a la junta de diputados de unas órdenes sobre el ceremonial del acto de instalación ${ }^{38}$, fijado para el 24 de septiembre, dejando en manos del nuevo organismo las pautas a seguir una vez constituido. La respuesta va a ser el Decreto del las Cortes del mismo día 24 de septiembre en donde se señalan las bases para la creación de un nuevo régimen jurídico, declarándose las Cortes legítimamente constituidas y titulares de la soberanía nacional ${ }^{39}$. Como órgano independiente y soberano asume las prerrogativas que le son propias y, entre ellas, la verificación de los poderes de sus miembros y la elaboración del Reglamento que ha de dirigir sus deliberaciones.

\section{4. ÁMBITO JURÍDICO DE APLICACIÓN DEL CONTROL ELECTORAL PARLAMENTARIO}

Nada dice la Instrucción de 1 de enero de 1810, como se acaba de ver, sobre la verificación de poderes como competencia exclusiva del Parlamento. La Constitución de 1812, de forma indirecta, asume la discutida prerrogativa, estableciendo en su artículo 115 que las Cortes «resolverán definitivamente y a pluralidad absoluta de votos, las dudas que se susciten sobre la legitimidad de los poderes y calidades de los diputados», y en los artículos 11 a 118, complementados por el capítulo II del Reglamento parlamentario de 1813, normativiza el control electoral

\section{1. Ámbito territorial}

La Junta Central establece, en la Instrucción de 1 de enero de 1810, las normas a que debe someterse la elección de diputados a Cortes en la península, no aludiendo a las celebradas en las posesiones españolas de ultramar. Una Instrucción del Consejo de Regencia de 14 de febrero de 1810, recién iniciado su mandato, es la que determina las normas electorales que deben seguir «aquella porción inmensa y preciosa de la Monarquía (...) para dar al próximo congreso nacional la representación completa del vasto imperio, cuyos destinos se le confían ${ }^{40}$. A fin

38 Real Orden del Consejo de Regencia de 18 de septiembre de 1810, a don Benito Hermida. A. C. Legajo 7.

39 M. Fernández Martín, op. cit., Documentos, pág. 624.

40 Archivo Congreso de los Diputados (A. C.), legajo 124, núm. 32. 
de lograr una representación aceptable de toda la nación española, que subsane los problemas originados por la distancia y las concretas situaciones políticas, se organizó una elección en Cádiz para diputados suplentes de las dos Américas y de las provincias peninsulares ocupadas por los franceses ${ }^{41}$, que irían siendo sustituidos por los auténticos propietarios según fuesen llegando. Desde el inicio del Congreso extraordinario se acuerda que entre suplentes y propietarios habría de existir siempre el número total de diputados designados ${ }^{42}$. Todos los electos, españoles peninsulares y americanos, debían de someter sus poderes al examen del Congreso soberano ${ }^{43}$.

Por tanto, desde el inicio del nuevo régimen, se concibe el ámbito territorial de aplicación del control electoral parlamentario como extensible a todos los territorios de la Monarquía. La Constitución de 1812, más explícita, considera a la nación española como la reunión de todos los españoles de ambos hemisferios y a las Cortes como la reunión de todos los diputados que representan la nación, nombrados por los ciudadanos en la forma que determinan las leyes ${ }^{44}$. El control de sus poderes correrá a cargo de la propia Cámara, con iguales características para peninsulares y americanos o filipinos. Esta concepción se mantendrá durante todo el siglo XIX, siendo afectada por la pérdida, lenta pero inexorable, del imperio de ultramar.

\section{2. Ámbito material}

Es necesario señalar qué documentos examina la comisión de poderes, quién está facultado para reclamar una elección y qué plazos existen para ello, en los comienzos de la institución de la verificación de poderes.

\section{a) Objeto del control electoral}

La Instrucción de 1 de enero de 1810 prevé el control electoral en cada uno de los niveles de elección, perteneciendo a cada junta electoral la decisión irrevocable sobre los casos de soborno y cohecho que se planteen ${ }^{45}$. En la elección del

41 Decreto del Consejo de Regencia de 8 de septiembre de 1810.

42 Diario de Sesiones (D. S.) de 23 de diciembre de 1810, pág. 218.

43 Orden de la Regencia sobre presentación y examen de poderes, de 11 de septiembre de 1810: «(...) de todos los procuradores de las provincias, ciudades, juntas y demás corporaciones de estos Reynos y los de Indias que hayan de asistir a las próximas Cortes». A. C. legajo 5, núm. 18.

44 Constitución española de 1812, artículos 1-10 y 27.

45 Instrucción de 1 de enero de 1810: cap. II, art. 12; cap. III, art. 10 y cap. IV, art. 8. 
último nivel, la junta electoral provincial extenderá a cada electo el poder, bajo la fórmula señalada taxativamente por la Instrucción ${ }^{46}$, que le servirá como credencial para presentarse ante la Cámara, y enviará a la Central ${ }^{47}$ el acta de elección ${ }^{48}$. Según lo acordado por la propia Cámara, la comisión de poderes ejercerá su control examinando el poder que personalmente entrega el electo, los recursos que lleguen al Congreso protestando la elección y los informes que la propia comisión de poderes solicite a cualquier organismo para elaborar su dictamen. Este control está más cerca del mero reconocimiento, ya que el formalismo del poder, como sombra del antiguo mandato imperativo, no muestra la auténtica dinámica de la elección ni los requisitos personales exigidos al electo por la Instrucción de 1 de enero de 1810, en cuanto a que deben reunir unas determinadas cualidades y su elección ha de cumplir determinadas formalidades y no haber sido acusado de cohecho o soborno ${ }^{49}$.

La Constitución de 1812 mantiene el que cada junta electoral, en los diferentes niveles, decida irrevocablemente sobre las dudas que puedan surgir en la celebración de las elecciones ${ }^{50}$ pero, buscando un control electoral más auténtico, exige que la comisión de poderes examine, junto al poder presentado por el electo, el acta de elección enviada por la junta electoral provincial a la Diputación permanente $^{51}$; además de estos documentos, conocerá las reclamaciones, si las hubiere, y los informes enviados por los diferentes organismos públicos a petición de la propia comisión ${ }^{52}$. La Constitución se limita a recoger la experiencia práctica sobre la inoperancia del poder para establecer el control que se pretende sobre legalidad de la elección y capacidad de los electos ${ }^{53}$, sin embargo este poder se mantendrá aún largo tiempo, no surgiendo en estas Cortes discusión alguna sobre su eficacia y permanencia

46 M. Fernández Martín, op. cit., Documentos, pág. 589.

47 Sin embargo, cuando se celebran las elecciones la Junta Central ya había sido sustituida por el Consejo de Regencia.

48 Instrucción de 1 de enero de 1810, cap. IV, art. 17.

49 Prueba de ello es la aprobación de los poderes de don Joaquín Tenreiro, examinados el 19 de septiembre de 1810 y hallados «corrientes», y denegados después de la instalación de las Cortes, cuya acta firma, por no ser natural del Reino de Galicia, a cuya provincia de Santiago representaba, primer requisito exigido en la Instrucción. A. C. legajo 7, núm. 25, y Adolfo de Castro, Cortes de Cádiz. Complemento a las sesiones verificadas en la isla de León y Cádiz. Imprenta de Prudencio Pérez de Velasco. Madrid 1913, pág. 343.

50 Constitución de 1812, artículos 49, 50, 70 y 85.

51 Constitución de 1812, artículos 101 y 104.

52 Datos deducidos de la lectura de los Diarios de Sesiones de 1810, 1811 y 1812.

53 Constitución de 1812, artículo 15 y Reglamento de 1813, artículo 17. 
En las Cortes de 1820 y 1822 ya se pone de manifiesto la necesidad de someter a deliberación las decisiones, inapelables legalmente, de las diferentes juntas electorales, ya que llegan a la Cámara reclamaciones que afectan a los distintos niveles de elección. Se rompe, pues, la línea establecida por la Instrucción de 1810 y mantenida por la Constitución de 1812 y, en la práctica, se somete a la Cámara el proceso electoral completo y no sólo el último nivel como estaba regulado $^{54}$. La comisión de poderes que ejerce la función verificadora en la segunda legislatura de este período, resume la actuación práctica de estas Cortes, puntualizando el auténtico cometido de las diferentes juntas electorales y ampliando el ámbito de aplicación del control parlamentario.

«Es cierto que existen en la Constitución tres artículos admirables contraídos a las tres juntas, que son, digámoslo así, los alambiques de los cuales resulta la representación nacional; a saber: las parroquiales, de partido y de provincia. Estos tres artículos están dirigidos a autorizar a las Juntas para que cada una de ellas, en su seno, resuelva sin apelación, las dudas que se ofrezcan; pero dudas se entienden aquellas que realmente lo son y tienen el nombre de tales, mas los principios sentados en la Constitución es imposible que nadie pueda calificarlos de dudas y mucho menos que Junta alguna tenga facultades para alterarlos ${ }^{55}$.»

Por tanto, la competencia de las Cortes en materia de verificación se extiende, en la práctica acordada en la Cámara, a todo el proceso electoral, dejando reducido el papel señalado a las juntas electorales a solventar aquellos problemas relacionados con el mantenimiento de un orden necesario para el desarrollo de la elección, pero nunca a opinar, ni menos, modificar las normas electorales plasmadas en la Constitución. De igual forma, en la práctica de estas Cortes, se observa el desconcierto de la comisión de poderes ante la diversidad de actas redactadas por las juntas electorales, que dificultan y oscurecen el examen que ha de realizarse sobre la elección; se solicita a la Cámara que apruebe un formulario de las actas "cuya variedad y disonancia llaman la atención del Congreso» ${ }^{56}$. También se pone de relieve la necesidad de examinar separadamente el acta de elecciones y el poder presentado por el electo, ante la evidencia de que puede ser correcto el segundo y viciosa la elección celebrada ${ }^{57}$.

54 Elecciones de Cuenca y de Jaén. D. S. 1 de julio de 1820, pág. 5.

55 Diputado Gareli. D. S. 23 de noviembre de 1821; $2^{\mathrm{a}}$ junta preparatoria de la segunda legislatura, pág. 8. Conviene precisar que el término legislatura ha de entenderse, en el sentido tradicional de nuestro derecho, como período de sesiones y no como Diputación.

${ }^{56}$ D. S. 24 de septiembre de 1820, pág. 1207.

57 D. S. 22 de febrero de 1822, pág. 32. 
b) Sujetos facultados para reclamar una elección o la capacidad de un electo

La comisión de poderes habrá de examinar las reclamaciones recibidas en la Cámara sobre algunos de los poderes presentados y que afectan a la legalidad de la elección o a la capacidad del elegido; pero ¿quién puede reclamar y cuándo puede hacerlo? Nada dice la legalidad vigente, siendo los acuerdos de la Cámara los que generen las costumbres parlamentarias que la normativa posterior recoge y elabora.

La Comisión de Cortes dirigida por Jovellanos en 1809, no había previsto un criterio sobre quién podía reclamar y por qué, ni tampoco la Instrucción de 1 de enero de 1810 ni la Constitución de 1812, entendiéndose en principio que todo aquél que no estuviese conforme con la elección podía dirigirse a la Cámara, admitiéndose todos los recursos, tanto sobre poderes no examinados como sobre aquéllos ya decididos. Las Cortes acuerdan, el 27 de septiembre de 1810, a solicitud del secretario Pérez de Castro, que cada particular pueda dirigir sus ideas a la Cámara, con el único límite de que no se les contestará por escrito, sino que simplemente se daría cuenta en público de ello ${ }^{58}$. El conocimiento por parte de la Cámara de las reclamaciones recibidas, estará sometido a su superior criterio; y así, con motivo de un escrito dirigido por don Trifón Ortiz de Pinedo, pidiendo su admisión y la exclusión del suplente, lleno de expresiones «poco decorosas», el soberano Congreso decide que «a este hombre se le imponga perpetuo silencio y no se le dé más castigo que el desprecio, no leyéndose su escrito ${ }^{59}$.

Por tanto, todo particular u organismo puede dirigir al Congreso una reclamación sobre la legalidad de una elección o la capacidad de un electo, decidiendo la Cámara sobre ella de acuerdo con su superior criterio. Pese a esta postura inicial de apertura a todo tipo de opiniones sobre elecciones, surge paulatinamente en el ánimo de los diputados la idea de que las reclamaciones puedan tener la única finalidad de entorpecer la reunión del órgano legislativo, con lo que las Cortes de 1820 acuerdan, ante el sinnúmero de acusaciones sin prueba que, si bien han de admitirse todas las reclamaciones, corresponde al acusador «justificar su aserto», a fin de que los diputados no estén expuestos al capricho o a la mala voluntad de cualquiera ${ }^{60}$.

58 D. S. 27 de septiembre de 1810, pág. 11.

59 D. S. 23 de diciembre de 1810, pág. 219.

${ }^{60}$ Sr. Moscoso D. S. 1 de julio de 1820, pág. 7. 
c) Plazos para ejercer las reclamaciones

Tampoco expresa nada la normativa vigente en esta etapa inicial sobre el plazo para presentar reclamaciones sobre la legalidad de una elección o la capacidad de un electo, y vuelve a ser la práctica parlamentaria la que irá generando una conciencia sobre la necesidad de someter toda actuación parlamentaria a normas jurídicas, en defensa de la propia seguridad y prestigio de la representación nacional. En un principio, pues, se admiten todas las reclamaciones, sin exigirse ningún plazo y pudiendo afectar tanto a elecciones no examinadas como a las ya decididas. El diputado liberal Argüelles solicita de la Cámara de 1810 un acuerdo, que no se toma, sobre la admisión de reclamaciones con posterioridad a una decisión sobre elecciones «para no volver a tomar en cuestión un negocio ya sancionado» ${ }^{61}$. En las Cortes de 1813 se actúa con igual criterio o, mejor, con igual falta de criterio, volviéndose sobre decisiones tomadas por la Cámara ante reclamaciones recibidas ${ }^{62}$

Las Cortes de 1820 tampoco fijan un límite legal para la admisión de reclamaciones, sometiendo la decisión sobre elecciones a la llegada de posteriores recursos: «si hubiere reclamación, las Cortes decidirán» ${ }^{63}$. Incluso se llega a anular una elección, aprobada en diferente período de sesiones, ante la llegada de un recurso en el actual ${ }^{64}$. Sin embargo, en las Cortes de 1822 se acuerda que no se pueda volver a debatir lo ya decidido, pues «la Constitución, con suma sabiduría ha resuelto que lo que se decida en las juntas preparatorias se entiende que es una decisión irrevocable y que ya no puede volverse a tomar en consideración» ${ }^{65}$; en consecuencia, este acuerdo conlleva la no admisión de reclamaciones posteriores al examen y decisión sobre una elección; acuerdo que la involución política dejará en el olvido.

Recapitulando, se observa una curiosa vía legal evolutiva, independientemente de los distintos momentos políticos que subyacen, que retoma las aportaciones anteriores y va creando un marco normativo adecuado, inmerso exclusivamente en el plano del deber ser, dejando que la práctica gubernamental y parlamentaria camine por derroteros cada vez más alejados de las previsiones legales.

61 D. S. 22 de diciembre de 1810, pág. 212.

62 D. S. 19 de enero de 1814, pág. 351. Suspensión de la admisión decidida sobre el diputado don Juan José Amorós, ante una reclamación posterior.

63 D. S. 1 de julio de 1820, pág. 7.

64 D. S. 23 de abril de 1821, págs. 5 y 7; expulsión de tres diputados admitidos en 1820 ante la llegada de reclamaciones que afectan a toda la elección en 1821, junto a la incorporación del cuarto diputado.

65 D. S. 2 de octubre de 1822, pág. 9. 
En el contenido del acta se centra el examen electoral desde el inicio del régimen constitucional, con independencia de reclamaciones que, aunque aceptadas legalmente, en la práctica son miradas con recelo y desechadas por insuficientemente probadas. El contenido del acta se interpreta desde el prisma de la defensa del legislativo como órgano independiente del ejecutivo, frente a las presiones de los partidarios del Antiguo Régimen, y ello desde un concepto unánime de Parlamento como órgano superior del Estado, no sometido ni a la ley ni a la misma Constitución

\section{PROCEDIMIENTO PARLAMENTARIO DE EXAMEN DE ACTAS ELECTORALES}

Será la propia práctica parlamentaria la que genere los acuerdos a que habrá de someterse la verificación de poderes como conquista del reciente poder legislativo; acuerdos que serán recogidos por las normas constitucionales, electorales y reglamentarias que se elaboran en el período histórico comprendido entre 1810, en que se inicia, y 1837, en que se consolida la nueva institución, concebida como prerrogativa indiscutida de las Cámaras parlamentarias de decidir sobre la capacidad de sus propios miembros y la legalidad de la elección que los ha nombrado.

Respecto al concepto de capacidad, su ausencia engloba tanto la inelegibilidad absoluta como la relativa. La primera afecta a quien, aún habiendo logrado la mayoría válida de votos, no reúne las condiciones objetivas exigidas para ser diputado, no pudiendo serlo por ninguna demarcación electoral. La inelegibilidad relativa afecta a quien no puede ser elegido por una determinada demarcación electoral, por ejercer en ella autoridad, pero sí podría serlo por otra. El concepto de legalidad se concibe, también desde el origen de la institución, como demostración de la regularidad de la elección, tanto en el sentido de sometimiento a las normas de procedimiento previstas para su desarrollo, como a la ausencia de falsedad, coacción o violencia en la misma

\subsection{Procedimiento inicial}

El Consejo de Regencia al delegar la competencia de verificar los poderes de los electos en los cinco diputados nombrados por él mismo ${ }^{66}$, no establece nin-

${ }^{66}$ Los componentes de esta Junta comienzan a utilizar el término de «Comisión de poderes». En los documentos del Archivo del Congreso se lee indistintamente «Comisión de examen de poderes de los diputados a Cortes» y «Junta para el reconocimiento de los poderes de los diputados». 
guna norma para que lleven a cabo su función, sino que se limita a ordenar que examinen los poderes de todos los diputados, citando el examen y aprobación, sin prever la posibilidad de una denegación ${ }^{67}$. Como ya se ha dicho, las indecisiones observadas en la actuación del Consejo de Regencia hasta la instalación del nuevo Congreso, encuentran su punto final en el Decreto del mismo 24 de septiembre de 1810, por el que las Cortes se declaran legítimamente constituidas y depositarias de la soberanía nacional ${ }^{68}$. Como órgano independiente y soberano asume las prerrogativas que le son propias y, entre ellas, la de verificar los poderes de sus miembros y establecer el Reglamento que va a regular su funcionamiento.

El 25 de septiembre, fecha siguiente a la solemne instalación de las Cortes extraordinarias, señaladas las bases para la creación de un nuevo régimen político, acuerda la Cámara que, ante la necesidad de examinar los poderes de los diputados que fuesen llegando, se nombrase por el Presidente una comisión de seis individuos, tres provenientes de la junta que en Cádiz había realizado esta función antes de la constitución del nuevo órgano, y tres de entre los demás componentes del Congreso. Esta comisión, que debía ser permanente, conocería sobre la legitimidad de los poderes y sobre las reclamaciones habidas, elaborando un dictamen sobre el que resolvería el pleno de la Cámara ${ }^{69}$. El acuerdo sobre el procedimiento a seguir por la nombrada comisión de poderes en el ejercicio de su función, sigue la línea señalada en su momento por la Comisión de Cortes de la Junta Central, fijando los siguientes puntos, según se deduce de las discusiones.

En primer lugar, legitimidad de los poderes, entendiendo por tal que el electo reúne los requisitos de capacidad exigidos por la Instrucción y que su elección se adapte a las formalidades señaladas taxativamente por aquélla y no exista cohecho o soborno. En segundo lugar, admisión de reclamaciones, a lo que no aludía la Comisión de Cortes. No se prevé un criterio sobre quién puede reclamar ni sobre qué, entendiéndose en principio que todo aquel que no estuviese de acuerdo con la elección. En tercer lugar, elaboración de un dictamen sobre la admisión o denegación del electo, sobre el cual decidirá el pleno. Por último, la Comisión de poderes será permanente, entendiéndose esta permanencia en el sentido de que su funcionamiento sea continuo y no en cuanto a una composición ad boc.

${ }^{67}$ Lo que sí había previsto la Comisión de Cortes en la Comunicación que presenta a la Junta Central. En M. Fernández Martín, obra citada, pág. 575.

${ }^{68}$ M. Fernández Martín, obra citada pág. 624. Se utiliza el término de «instalación» para aludir a la constitución de la Cámara.

69 Según lo acordado, el Presidente Lázaro de Dou nombró al Marqués de Villafranca, Oliveros y Amat, de la antigua comisión, y a los señores Utgés, Lladós y Zorraquín. D. S. 25 de septiembre de 1810, pág. 6. 
Por tanto, tras esos mínimos acuerdos, las reglas concretas de actuación han de ir surgiendo de la propia práctica parlamentaria, en torno a la problemática que se plantea día a día, dado que las elecciones se llevan a cabo de una forma totalmente irregular debido a la situación bélica del país. Continuamente llegan nuevos diputados a incorporarse a la Cámara, jurando a continuación de ser admitidos. Sobre lo dicho se pueden señalar los siguientes datos:

- El 27 de septiembre, el secretario Pérez de Castro, ante un escrito sobre la ilegitimidad de ciertos poderes, solicita de las Cortes un acuerdo sobre que cada particular puede dirigir al Congreso sus ideas, de las que dará cuenta en público, pero a ninguno se le contestará por escrito, salvo al Gobierno, pues lo demás sería «interminable, incongruente e impracticable» ${ }^{70}$.

- El 1 de octubre se decide que la discusión se realizará en sesión secreta, debido a que podrían ocurrir incidentes u observaciones personales. Este punto supone un retroceso respecto a la defensa de la idea liberal de que el pueblo tuviese conocimiento de las decisiones del poder, en contra de la opinión de secreto oportuno propia de la Ilustración. Durante los trabajos de la antigua Comisión de Cortes se había discutido el problema de la publicidad de las sesiones del Congreso, llegándose a la conclusión, así expuesta a la Junta Central en su Comunicación, de que la publicidad era beneficiosa y produciría la confianza del pueblo. Sin embargo, a los pocos días de su instalación, las Cortes acuerdan el secreto de determinadas sesiones, con el argumento de respeto a la persona. En esta misma línea se estableció el que a los diputados electos no admitidos, se les diese un certificado exponiendo que su denegación no era debida a defectos personales del individuo sino a la no adaptación a lo exigido en la Instrucción de 1810, dejando bien clara la honorabilidad del ciudadano y, en suma, el prestigio del cuerpo al que iba a pertenecer ${ }^{71}$.

- Desde el comienzo de su funcionamiento y para llevar a cabo sus trabajos, la Comisión de poderes acuerda solicitar a otros organismos los documentos necesarios para elaborar un informe riguroso ${ }^{72}$.

- Respecto a los trámites burocráticos seguidos por el electo en el momento de su incorporación, se puede deducir de la lectura de los propios Diarios de Sesiones que el diputado electo presenta sus poderes al Secretario de las Cortes, quien los entrega al Oficial mayor de la Secretaría; éste, a su vez, los registra y los envía a la Comisión de poderes

${ }^{70}$ D. S. 27 de septiembre de 1810, pág. 11.

${ }^{71}$ D. S. 20 de julio de 1812, pág. 3.450.

72 D. S. 18 de octubre de 1810, pág. 51. 


\subsection{El Reglamento provisional de 1810}

El 27 de noviembre de 1810 se aprobó un Reglamento por el gobierno interior de las Cortes que no se comunicó al Consejo de Regencia ni se incluyó en la Colección de Decretos de las Cortes ${ }^{73}$. De esta forma se manifiesta claramente la independencia del legislativo en cuanto a su constitución y funcionamiento, en que nada tiene que decir, ni menos vetar, el ejecutivo, y la determinada naturaleza jurídica del Reglamento de la Cámara, como interna corporis acta, cuyos destinatarios son únicamente los diputados, con lo que no tiene que seguir las formalidades de las demás normas dictadas para el resto de los ciudadanos del Estado. En este Reglamento no se regula específicamente la Comisión de poderes, sino dentro de la normativa general de las comisiones $^{74}$. Se mantiene el que el Presidente de la Cámara nombre a los individuos que compondrán las comisiones, fijando su número en un máximo de cinco y un mínimo de tres, que se renovará por mitad cada dos meses. La comisión no podra decidir cosa alguna en los asuntos que se le encarguen, sino que elaborará un informe, firmado por todos sus componentes, que presentará al pleno; el disconforme con el dictamen mayoritario expondrá su opinión fundamentada. Por tanto, de dan entrada en este primer Reglamento a los votos particulares de los miembros de la Comisión. Por último, autoriza a la comisión a solicitar a otros organismos los documentos necesarios para una mejor información, sin «limitación alguna» ${ }^{75}$.

Llama la atención en este Reglamento ${ }^{76}$, muy simple por otro lado, la ausencia de una formulación jurídica sobre la competencia de verificación parlamentaria que asumen las Cortes por encima y en contra de la tradición histórica, como base irrenunciable de su autonomía e independencia; el Congreso deja que sean los acuerdos de la Cámara, nacidos al socaire de los conflictos planteados, los que generen las normas de funcionamiento que recogerán la Constitución de 1812 y el Reglamento de 1813.

73 Según consta en la Colección de Reglamentos del Congreso de los Diputados. Secretaría de las Cortes, Madrid 1977.

74 Reglamento de 1810, capítulo VII, artículos 3-9.

75 Idem, artículo 1.

76 Que regirá, en cuanto al examen electoral, durante el funcionamiento de estas Cortes, pues el siguiente, elaborado tras la aprobación de la Constitución de 1812, es de fecha 4 de septiembre de 1813, siendo aplicado en las Cortes ordinarias. 


\subsection{El Reglamento de 1813: primera regulación del procedimiento de verificación de poderes. El Reglamento de 1821 como continuación del anterior}

Antes de finalizar sus trabajos, las Cortes extraordinarias aprueban un Reglamento $^{77}$, coordinado con la Constitución, destinado a regular actuaciones de Congresos posteriores. La Constitución de 1812 no hace una formulación de principio sobre la verificación de poderes como prerrogativa perteneciente a la Cámara, limitándose a regular su ejercicio práctico, en cuanto que determina las normas que han de seguirse para examinar los poderes de los diputados, normas que complementa el Reglamento de 1813 y que recogen los acuerdos parlamentarios existentes ${ }^{78}$. La Comisión de Constitución, al presentar el proyecto de Reglamento, expone a la Cámara que sólo se realizarán aquellas variaciones que la experiencia de tres años manifestó convenientes, pues la práctica es la maestra fundamental ${ }^{79}$. Los puntos principales de esta regulación son los que a continuación se señalan.

- Los diputados, al llegar a la ciudad en donde esté prevista la reunión de las Cortes, se presentarán a la Diputación permanente, y en la secretaría de las mismas Cortes quedará registrado el nombre del electo y el de la provincia que lo eligió. En la primera junta preparatoria, en la que actuará de Presidente el que lo sea de la Diputación permanente, se leerá, por uno de los secretarios, la lista de los presentados, quienes entregarán sus poderes.

- En esta primera junta preparatoria se nombrarán dos comisiones de poderes; este nombramiento deja de ser una función del Presidente para pasar a serlo de los diputados presentes, a pluralidad de votos ${ }^{80}$.

- Una de las comisiones examinará los poderes de todos los diputados, excepto los suyos, y constará de cinco individuos; la otra, formada por tres, examinará los poderes de los anteriores.

- A estas comisiones se entregará toda la documentación recibida para que elabore su informe, teniendo presente las actas de las elecciones provinciales relativas a la concreta elección de los diputados. Dentro del concepto de documentos que habrá de examinar la comisión, se puede deducir de la lec-

77 Presentado por la Comisión de Constitución el 12 de agosto de 1813, fue aprobado sin discusión en cuanto a la verificación de poderes el 4 de septiembre de 1813.

78 Artículos 111 a 117 de la Constitución de 1812 en relación al 14 a 26 y 80 a 83 del Reglamento de 1813 .

79 D. S. 12 de agosto de 1813, pág. 5945.

80 D. S. 15 de septiembre de 1813, pág. 877. 
tura de los Diarios de Sesiones, pues nada especifica el Reglamento, que se entregarán a la comisión los recursos que lleguen a la Cámara protestando alguna elección y aquellos informes que envíen otros organismos a petición de la propia comisión de poderes; posibilidad que ya había recogido el Reglamento de 1810, pero que limita el artículo 79 del de 1813 al exceptuar de dicha petición de información aquellos documentos que exijan secreto, cuya violación pueda perjudicar al servicio público.

- En la segunda junta preparatoria, las comisiones presentarán sus dictámenes a puerta abierta. Se prescinde, ya elaborada la Constitución, de la sesión secreta, aunque saldrá fuera del salón aquel electo de cuyos poderes se trate. Los informes de la comisión serán firmados por todos sus miembros, debiendo el que discordare, fundamentar su opinión. Se comienzan a examinar aquellos poderes que no presenten dudas, dejando para el final los conflictivos, buscando el que en su discusión participen el mayor número de diputados.

- El Reglamento exige que sólo participen en las discusiones aquellos diputados cuyos poderes ya hayan sido aprobados; es decir, se deduce que sólo se considera diputado aquel que haya sido admitido, siendo el no examinado un mero electo.

- Tras la discusión del dictamen presentado por la comisión, se tomará la decisión por mayoría absoluta de votos; nada dice el Reglamento sobre su irrevocabilidad, pero sí la Constitución, al señalar que «resolverá definitivamente». En la práctica no fue así. Se celebrarán todas las sesiones que sean necesarias para que queden examinados los poderes de los diputados presentes, de forma que en la tercera junta preparatoria, con asistencia de los admitidos, se jure y se elija al Presidente, vicepresidente y Secretarios, quedando constituida la Cámara.

- Tanto la Constitución como el Reglamento señalan fechas concretas para la realización de todos los actos previstos, dando un plazo de quince días para la celebración de las tres juntas preparatorias y la constitución de las Cortes. Esta fijación de fechas responde al afán de las Cortes extraordinarias en dejar todo previsto para la celebración de las posteriores, con ese intento de permanencia que tuvieron todos sus actos y que la práctica se encargó de derribar.

- Según determina el capítulo correspondiente a la regulación general de las comisiones, éstas se pueden renovar por mitad cada dos meses; continúa, pues, siendo permanente la comisión de poderes en cuanto a grupo de trabajo pero no en cuanto a los individuos que lo componen. 
La regulación establecida en este Reglamento, en cuanto al procedimiento de verificación de poderes, es mantenida por el elaborado en las Cortes de 1820, convocadas tras el restablecimiento del régimen constitucional por Fernando $\mathrm{VII}^{81}$. Esta nueva norma recoge determinados acuerdos de las Cámaras anteriores surgidos de la práctica diaria. Los artículos concernientes a la verificación de poderes son aprobados sin discusión en la sesión de 16 de marzo de 1821, formando el tercer Reglamento de la historia parlamentaria española, con una vigencia propia muy limitada, pero que será punto de partida de regulaciones posteriores.

Como artículos novedosos se pueden citar los siguientes. En primer lugar, el artículo 16 que, manteniendo la norma de que debe de salir del salón de sesiones el diputado de cuyos poderes se trate ${ }^{82}$, la amplía en el sentido de que, sin embargo, podrá exponer antes lo que tuviere por conveniente; responde este artículo a la aceptación práctica de la Cámara, en varias ocasiones y pese a alguna protesta individual en pro de la regulación parlamentaria, respecto a que el diputado discutido pudiese hablar antes de abandonar la sala ${ }^{83}$. En segundo lugar, en cuanto a la organización interna de la propia comisión de poderes, el artículo 96 determina que cada comisión nombrará un secretario de entre sus miembros, que será responsable de los documentos y expedientes que se pasen a la misma, llevando un registro formal de entrada y salida, de acuerdo con el de la Secretaría de las Cortes. Este Reglamento de 1821 recoge las regulaciones anteriores y es punto de referencia en varios momentos históricos, más que por el valor de su contenido, por lo que representa políticamente.

A través de los Reglamentos señalados se regula el procedimiento de verificación de poderes, fundamentalmente apoyados en la práctica parlamentaria. Existe una línea evolutiva en las diferentes normas reglamentarias recogiendo las aportaciones anteriores y profundizando en su elaboración; sólo la forma de elección de los componentes de la comisión de poderes es motivo de discrepancias entre uno y otro Reglamento: la inicial elección por el Presidente y la posterior elección por la Cámara en 1813 y 1821. Respecto al procedimiento de verificación de poderes, se puede señalar un primer momento en el que la comisión elabora un dictamen con absoluta libertad y sin debate alguno entre las partes; desde 1813 existe la posibilidad de manifestar las discrepancias entre los miembros de la comisión, mediante los votos particulares. En un segundo momento, y con unas mínimas garantías para el discutido, se inicia el debate público del dictamen con posibilidad de defensa del electo desde 1821. Por último, y esencial-

81 Reglamento de 29 de junio de 1821.

82 Artículo 16 del Reglamento de 1813.

83 D. S. 1 de julio de 1820, pág. 7. 
mente, la Cámara decide con absoluta libertad, pudiendo alejarse del dictamen de la comisión; es decir, frente a un dictamen jurídico puede tomarse una decisión política. La función de la comisión es la instrucción de un expediente que se respetará, o no, en función de otros criterios.

\section{PRÁCTICA PARLAMENTARIA DE LA VERIFICACIÓN DE PODERES ${ }^{84}$}

El hilo conductor de todas las deliberaciones llevadas a cabo en las Cámaras de $1810,1813,1820$ y 1822 , pese a la variabilidad aparente de criterios, es la defensa del Legislativo frente a un Ejecutivo enfrentado a él y empeñado en una lucha constante por reasumir cada una de las prerrogativas de las que se ha visto privado y, fundamentalmente, la titularidad de la soberanía. Así, las Cortes de 1810, desde su arbitrariedad, desechando a quien no es liberal y partidario, por tanto, de un Congreso independiente y soberano. Las Cortes de 1813, desde la lenidad de admitir a todo diputado, independientemente de su ideología, buscando un respaldo general al régimen establecido por la Constitución de 1812, frente al imprevisible criterio del Rey Fernando VII. Tras la involución política, las primeras Cortes del trienio liberal, con su tolerancia, obvian las tachas salvables, en pro de la consolidación del régimen constitucional y del Parlamento soberano, aceptado forzadamente por el Rey. Como excepción, las Cortes de 1822 son diferentes ${ }^{85}$ en cuanto a que cierta estabilidad política sustituye la lucha Parlamento-Corona por la lucha mayoría-minoría, excepción que es anuncio de lo que va a ser la verificación de poderes a partir de 1837, en que se consolida el régimen constitucional. En suma, etapa que rompe con la concepción tradicional de la Corona, iniciando un largo proceso de asentamiento de un régimen representativo a través de un Parlamento independiente; independencia manifestada fundamentalmente en su competencia para decidir definitiva y arbitrariamente sobre la legalidad de las elecciones y la capacidad de los electos. Las Cortes se

84 Si interesa ver el estudio pormenorizado de los casos examinados en cada legislatura, ver C. Fdez-Miranda Campoamor, la Verificación de Poderes citada. Debido a la limitación necesaria de este trabajo, vamos a aportar solamente los criterios jurídico-políticos aplicados en la verificación de poderes, deducidos del estudio puntual de cada uno de los debates. Conviene recordar que el período de elaboración y aplicación de la Constitución de 1812 corresponde a las Cortes de 1810 , 1813,1820 y 1822.

$85 \mathrm{Y}$, en el mismo sentido, las de 1836. Hay que tener en cuenta que este primer período, 1810-1837, inicia el régimen constitucional en España y la verificación de poderes responde a criterios similares. En este estudio, por razones obvias, nos centramos en la etapa de elaboración y aplicación de la Constitución de 1812. 
sienten soberanas, con un poder ilimitado que les va a permitir tomar decisiones en contra de la ley y aún de la misma Constitución. Su actuación se corresponde al sentimiento general de la opinión y, en este sentido, es coherente y justificada; frente a los argumentos defensores de la legalidad prima el superior criterio político, criterio que puede subsumirse — como se ha dicho- en la defensa del Parlamento frente a los intentos absolutistas de la Corona, en una tensión permanente entre ambos poderes.

\subsection{Criterios jurídico-políticos aplicados en las Cortes Constituyentes de 1810}

En primer lugar, no existe un criterio fijo en la actuación de las comisiones, sino que en varias ocasiones una comisión anula lo hecho por la anterior En la práctica, pues, la decisión de las Cortes no se considera «cosa juzgada», puesto que se admiten recursos contra lo ya acordado, se vuelve sobre discusiones ya cerradas e, incluso, se revocan las decisiones. La voz solitaria del diputado Argüelles rogando a la Cámara que mantenga un criterio, no recibe ninguna respuesta por parte de ésta.

En segundo lugar, estas Cortes fueron arbitrarias; es decir, no existió un criterio unánime para decidir; un mismo problema se contempla desde distinto prisma según quién sea la persona en quien concurre. La Cortes se consideran superiores a toda norma, incluso a la norma fundamental, y su interés fundamental reside en conseguir el número de diputados necesario para respaldar todas las reformas que se quieren realizar. El patriotismo y la oportunidad política son los argumentos de peso que deciden las votaciones, frente a todo tipo de ilegalidades por no haberse adaptado la elección a las formalidades o a las condiciones de capacidad exigidas por la Instrucción de 1810. Por tanto, el motivo que prima no es el cumplimiento de a ley, sino el patriotismo demostrado por el electo, bien como partidario de las reformas que se quieren imponer (curiosamente por un grupo minoritario aunque consciente y organizado) o bien por haber actuado en contra del invasor ${ }^{86}$, y la oportunidad política, entendida en el sentido de que todas las provincias tengan representación en las Cortes, como respaldo a la Constitución que se quiere aprobar o que ya se ha aprobado ${ }^{87}$. Es más patente este interés respecto a los diputados americanos, aceptando a los enviados por los

${ }^{86}$ El haber aceptado algo del gobierno intruso se considera crimen o reato, de lo que se exige purificación. Informe de la comisión de poderes, D. S. 8 de febrero de 1813, pág. 4675.

87 Debido a las circunstancias de guerra en todo el país, las elecciones es van desarrollando en diferentes momentos y según la situación de cada provincia, de forma que los diputados se irán incorporando, paulatinamente, hasta el final del mandato 
diferentes gobiernos y cerrando los ojos ante las ilegalidades realizadas en sus elecciones, con la finalidad de paliar la situación de recelo o indisciplina que empieza a ser normal en América. A lo dicho hay que añadir que es evidente que existen personas no gratas, ante las cuales se aplica la ley.

Por último y abundando en el interés de estas Cortes por dejar patente su legitimidad y el apoyo mayoritario a la labor legislativa realizada, conviene exponer el enfoque práctico dado al problema de los suplentes elegidos en Cádiz, en su mayoría liberales. Desde el primer momento se acuerda que, entre los propietarios que se fuesen incorporando y los suplentes presentes en la Cámara, debía de existir el número total de diputados designados ${ }^{88}$. Durante todo el funcionamiento de las Cortes, los suplentes fueron considerados, en todo, iguales a los propietarios; incluso se acordó que no se expresase esta distinción a la hora de firmar la Constitución política de la Monarquía; hay que tener en cuenta también que algunos suplentes pasaron posteriormente a la categoría de propietarios, al ser elegidos por sus provincias cuando pudieron celebrarse elecciones ${ }^{89}$. La importancia de este tema es su incidencia directa en la legitimidad de la instalación y afecta al interés del Congreso en tener un respaldo inatacable a su labor jurídica, principal motivo de su actuación: «(...) el dudar un solo momento de la igualdad de los diputados, a más de ser contrario a diferentes resoluciones del Congreso, atacaba a su legitimidad, solemnemente reconocida y sancionada en el Decreto de 24 de septiembre de 1810, con el cual las Cortes se declaraban legítimamente constituidas $(\ldots){ }^{90}$.

\subsection{Criterios jurídico-políticos aplicados en las Cortes de 1813}

La lenidad es la característica más sobresaliente de las Cortes ordinarias. Las de 1810 fueron arbitrarias porque se sentían omnipotentes; estas Cortes, hijas de las anteriores, dan la impresión de haber sido privadas de toda fuerza por sus progenitoras; a ellas se remiten en todo y subyace en sus actuaciones un fuerte recelo ante la próxima llegada del Rey. Debido a la disposición constitucional que incapacita para ser diputado en las ordinarias al que lo hubiese sido en las extraordinarias, las Cortes de 1813 se vieron privadas de los hombres de prestigio que se habían generado en las anteriores; esto, unido a la exigencia constitucional de incompatibilizar para el cargo de diputado a los secretarios de despacho, hace que las Cortes de 1813, con la excepción de una minoría de

88 D. S. de 23 de diciembre de 1812 , págs. 4153 y ss.

89 D. S. de 18 de diciembre de 1811, pág. 2443.

90 D. S. de las Cortes ordinarias de 12 de agosto de 1813, pág. 5930. 
hombres prestigiosos, se muestren aisladas, atemorizadas y carentes de la fuerza y brillantez que hubiera posibilitado su enfrentamiento con el Rey. Así como las Cortes gaditanas, desde su poder soberano y consecuentes con él, desecharon personas no gratas, estas Cortes sólo buscan número pero no calidad, lo que explica el que para desarrollar la Constitución de 1812 se instalen unas Cortes en que gran número, 68 diputados, se manifestaran ante el Rey como partidarios de una reforma, pero no de la realizada en Cádiz. Las dos únicas denegaciones que se han podido constatar son debidas a acusaciones de crimen o reato, que en estos momentos son los delitos más castigados. El resto de las ilegalidades son obviadas por la conveniencia política de admitir a todo diputado que se presente. Ellas mismas originaron su destrucción al aceptar a los representantes de todas las tendencias políticas, no por respeto a la ley, pues se sienten superiores a ella, sino buscando un respaldo nacional ante el Rey a la labor realizada por las Cortes del año 12, labor que ya se manifestaba como sólo sostenida por una minoría extremista. Por último, la decisión tomada sobre los poderes examinados, se ve a través de la práctica que sigue sin ser definitiva. En suma, necesidad de defender unas Cortes diferentes a las tradicionales, base de un régimen político nuevo, cuya legitimidad es puesta en entredicho por muchos $^{91}$, es admitida de manera forzada por otros $\operatorname{tantos}^{92}$ y es defendida íntegramente por muy pocos ${ }^{93}$.

\subsection{Criterios jurídico-políticos aplicados en las Cortes de 1820}

Existe un criterio de tolerancia en la Cámara que, aunque aparentemente se puede confundir con la lenidad propia de las Cortes de 1813, es diferente de aquéllas porque responde a planteamientos distintos. Frente a la necesidad de las Cortes ordinarias de legitimar la obra jurídica de 1812 ante la nación y al ya esperado Fernando VII, con el consiguiente recelo manifestado en todas sus actuaciones, las Cortes de 1820 son tolerantes porque poseen la euforia propia de un triunfo político que, en estos momentos, aún se cree definitivo, y porque la mayoría electoral pertenece a la familia liberal, aún no dividida ni enfrentada,

91 D. S. 3 de octubre de 1813, pág. 50: exilio voluntario del Obispo de Astorga por no poder, en conciencia, publicar el Decreto sobre la Inquisición.

92 A través de los Diarios se constatan numerosas elecciones realizadas sin haber jurado la Constitución. D. S. de 23 de julio de 1813, pág. 5785. Sobre lo expuesto en este epígrafe ver Murillo Ferrol, F «El manifiesto de los Persas y los orígenes del liberalismo español», en Homenaje a $N$. Pérez Serrano, T. II., Reus, Madrid 1959.

93 Discurso de Argüelles. D. S. 30 de marzo de 1813, pág. 4930. 
mientras que los absolutistas, acobardados junto al Rey, no participan en esta primera contienda electoral. En esta Cámara se encuentran los más prestigiosos nombres liberales: Quintana, Toreno, Ramos Arispe, Istúriz, Martínez de la Rosa, Villanueva, Muñoz Torrero, Cano Manuel, Romero Alpuente, Martínez Marina, Flórez Estrada, Espiga etc que posteriormente irán distanciándose dentro de fracciones diferentes. Prima, pues, el principio de oportunidad política, en razón de la suprema salud del Estado, como defensa de la reunión del Parlamento. Tampoco en estas Cortes se considera «cosa juzgada» la decisión de poderes tomada por la Cámara, pudiendo volverse sobre ella. La idea que domina en las Cortes, sobre la salud del Estado, es expuesta por Martínez de la Rosa con motivo de debatirse los poderes de los suplentes -elegidos en Madrid- de los diputados americanos, no llegados en la fecha prevista para la constitución de la Cámara:

«(...) el medio supletorio es el único que se conoce cuando circunstancias extraordinarias impiden la reunión de los propietarios (...) en situaciones difíciles hay que pasar de ligero sobre la escrupulosidad de ciertos principios, cuya rígida observancia debería de reclamarse en otras circunstancias. Porque si se hiciese una rigurosa aplicación de ellos, quizá no habría ninguna representación legítima, ninguna revolución que lo fuese, y aún estas mismas Cortes no estarían bien constituidas $^{94}$.»

\subsection{Criterios jurídico-políticos aplicados en las Cortes de 1822}

Estas Cortes, en sus decisiones, son arbitrarias, primando sobre la aplicación de la ley la razón política de una admisión, bien por motivos de oportunidad política o de patriotismo, entendido éste desde el prisma de la mayoría liberal, o bien por el motivo de férrea defensa de la independencia del Parlamento frente a la intervención del poder ejecutivo en las elecciones, considerado como enemigo de la libertad. Es decir, las decisiones tomadas en cada momento no se someten a criterio fijo, inexistente, sino que son arbitrarias acomodándose al interés político sobre la aprobación o denegación de los poderes discutidos. Respecto al valor jurídico de la decisión del Congreso, se califica como «cosa juzgada», en una interpretación diferente al de otras Cámaras y mucho más coherente, en defensa de la inapelabilidad de las decisiones parlamentaria

«(...) si se pudiesen tratar de nuevo si debían o no ser aprobados los poderes siempre que hubiesen de reunirse la Cortes, podría darse lugar a un mal muy grande,

${ }^{94}$ D. S. de 15 de agosto de 1820 , pág. 527. 
cual sería el de proporcionar tal vez medios para que el espíritu de partido pudiese influir en las deliberaciones del cuerpo legislativo; y, por consiguientes, la Constitución con suma sabiduría ha resuelto que lo que se decide en las juntas preparatorias se entiende que es una decisión irrevocable y que ya no puede volverse a tomar en consideración ${ }^{95}$.»

\section{FUNDAMENTO Y NATURALEZA DE LA VERIFICACIÓN DE PODERES EN EL PERÍODO 1810-1822. RECAPITULACIÓN}

Pese a que el período de instauración del régimen constitucional consideramos que finaliza con la Constitución de 1837, por razones obvias vamos a centrarnos -a modo de recapitulación- en la etapa 1810-1822, exponiendo el concepto que sobre la verificación de poderes, como decisión de naturaleza política, se va generando y consolidando en la práctica.

\subsection{Discusión de legitimidades con anterioridad a la constitución de las Cortes de $1810^{96}$}

El Consejo de Castilla, órgano a quien correspondía la verificación de poderes de los procuradores en el antiguo régimen, actuaba como un tribunal administrativo de justicia - "tribunal recto e imparcial"- cuya función era claramente judicial, en el sentido formalista clásico de órgano que dirime conflictos jurídicos mediante la aplicación técnica de la ley y que nada tiene que ver con la concepción actual de órgano judicial que requiere independencia funcional y orgánica. De acuerdo con lo dicho, en el escrito señalado que el Consejo de Castilla envía al Consejo de Regencia el 14 de septiembre de 1810, alega como argumento fundamental en contra del examen parlamentario de los poderes, que tal reconocimiento no deben hacerlo los mismos apoderados, pues serían jueces y partes. A su vez, en las conclusiones que la Junta de Ceremonial presenta a la Comisión de Cortes para la elaboración del informe que ésta debía elevar a la Junta Central, pese a la ruptura con el mandato imperativo anterior y la atribución a la Cámara del examen de poderes, se concibe aún tal función como judicial, exigiéndose a los habilitadores a quienes corresponde su ejercicio, un juramento ante el Presidente de la Junta Central, como un tribunal dependiente del Rey, y actuar con imparcialidad y respeto a la ley: «Servir fiel y legalmente su empleo (...)

\footnotetext{
95 Sr. Diputado Romero. D. S. de 2 de octubre de 1822, pág. 9.

96 Datos ya expuestos y recogidos en A. C. legajo 5, número 18.
} 
sin separarse jamás de lo justo por respeto alguno, ni inclinarse a favor de nadie por amistad, parentesco ni otro motivo». A los habilitadores corresponde la aprobación, en el sentido señalado, de los poderes correctos pero, sobre los conflictivos, se eleva a las Cortes un dictamen para que éstas decidan. En este punto se encuentra implícito el origen de la nueva naturaleza de la verificación como decisión política de la Cámara.

La Comisión de Cortes dirigida por Jovellanos, en su comunicado de 8 de noviembre de 1809, a la Junta Central, junto al proyecto de Instrucción de normas electorales, prescinde de la intervención del ejecutivo como receptor del juramento de los habilitadores, como tribunal dependiente del Rey, pero mantiene el que aquéllos aprueben por sí los poderes correctos adaptados a la Instrucción de 1 de enero de 1810 y eleven un dictamen a la Cámara sobre los conflictivos, para que ésta decida en última instancia. Parece, pues, que en este informe se rompe tajantemente con la jurisdiccionalidad del control electoral, dejando toda situación conflictiva en manos de la decisión independiente de la Cámara, sin especificar ningún rasgo que caracterice tal decisión, pero dándole una amplitud que será recogida por el nuevo Congreso tras su constitución el 24 de septiembre de 1810 .

\subsection{Concepción parlamentaria sobre la verificación de poderes}

Las Cortes de 1810, en el Reglamento provisional de 27 de noviembre, privan a las comisiones de poderes de decisión alguna, limitando su función a elaborar un informe que se elevará al Congreso, quien decidirá «con la plenitud de sus poderes». Por tanto, desde el comienzo de su mandato, las Cortes es consideran como un poder originario creador de una legalidad nueva y, en consecuencia, su decisión sobre poderes no será judicial sino política y no sometida a control alguno. Se consideran titulares de un poder omnímodo y tal concepción es compartida por particulares y corporaciones. Fernández Martín considera que aquellas Cortes tenían un concepto de su soberanía muy similar, sino idéntico, al que tenían de la suya los Monarcas absolutos ${ }^{97}$. Es decir, el Congreso es superior a toda norma y a toda crítica y no se considera un tribunal aplicando la ley, sino un cuerpo político decidiendo, con absoluta libertad, con criterios políticos. La misma comisión de poderes, ante un recurso del ayuntamiento de Sevilla, a causa de una anulación, solicitando que «V. M. se digne rever la acta», exclama indignada:

${ }^{97}$ Derecho parlamentario español, citado, Tomo I, pág. 65. 
«(...) dónde se ha visto que un ayuntamiento forme expediente y lo pase a los síndicos para que expongan su parecer sobre una decisión del soberano Congreso, que abiertamente se le desobedezca y que, como si fuese un tribunal, se suplique su declaración $?^{98}{ }^{» »}$

Esta idea se deduce de la lectura de los Diarios de Sesiones, pero aún no es formulada taxativamente; sin embargo, sí se observa el tono despectivo con el que la comisión de poderes alude a «como si fuese un tribunal» sujeto a la ley. La tesis de la soberanía parlamentaria está implícita en las actuaciones del Congreso, cuya decisión legitima toda situación que considere necesario aceptar, todo está legitimado por el superior criterio del Congreso.

Las verificaciones realizadas responden a este pensamiento y, dentro de él, son adecuadas y coherentes: sobre la ley e, incluso, sobre la misma Constitución, hay un organismo superior cuya decisión puede subsanar cualquier elección ilegal o admitir a cualquier electo incapaz si existe un interés político que lo reclame. Las Cortes posteriores, durante la etapa de vigencia de la Constitución de 1812, asumen esta concepción política sobre la decisión de la Cámara en el examen de actas electorales. Esta concepción niega naturaleza jurídica a la verificación de poderes, considerando la decisión de la Cámara puramente política y justificadora de cualquier extremo ante el valor superior de la salud del Estado y la defensa del régimen constitucional; la arbitrariedad del Congreso es entendida como actuación propia de un cuerpo superior a cualquier tribunal, que decide sin control alguno.

Esta ajuricidad con que desde el inicio del régimen constitucional se concibe la decisión que el Parlamento ha de tomar sobre la legalidad de las elecciones y la calidad de los electos, ha de entenderse como defensa del órgano legislativo frente a la Corona, en su afán por recuperar las prerrogativas de las que se ha visto privada.

\section{BIBLIOGRAFÍA}

\section{Obras generales}

Alcalá Galiano, A. (1845). Lecciones de Derecho Político Constitucional. Madrid. D. J. Boix.

Artola Gallego, M. (1974). Partidos y programas políticos, 1808-1936. Madrid. Aguilar.

- (1975). Los orígenes de la España contemporánea. Madrid. IEP.

AzCÁRAte, G. (1885). El régimen parlamentario en la práctica. Madrid. Fortanet.

${ }^{98}$ D. S. de 22 de febrero de 1813, pág. 4738. 
Borrego, A. (1885). Historia parlamentaria de España durante el siglo XIX. Madrid. A. Rodero. CARR, R. (1970). España: 1808-1939. Barcelona. Ariel.

Colmeiro, M. (1870). Elementos de Derecho Político y Administrativo de España. Madrid. Imp. De F. Martínez García.

Elorrieta y Artaza, T. (1916). Tratado elemental de Derecho Político comparado. Madrid. Reus.

Fábregas, J. (1922). Derecho Político. Madrid. Reus.

Fernández MarTín, M. (1885). Derecho parlamentario español. Madrid. Imp. de los hijos de J. A. García. 3 tomos.

Ilbert, P. (1926). El Parlamento. Barcelona. Labor.

ÍzAgA, L. (1952). Elementos de Derecho Político. Barcelona. Bosch.

LAfuente, M. (1890). Historia General de España desde los tiempos primitivos hasta la muerte de Fernando VII. Continuada desde dicha época hasta nuestros días por don Juan Valera con la colaboración de don Andrés Borrego y don Antonio Pirala. Barcelona

Martínez Marina, F. (1813). La teoría de las Cortes o grandes juntas nacionales de León y Castilla. Madrid

- (1979). La teoría de las Cortes. Madrid. Editora Nacional

Palacio Atard, V. (1957). La España del siglo XIX. Barcelona. Seix Barral.

PONS y UMBerT. (1906). Organización y funcionamiento de las Cortes según las Constituciones españolas. Madrid

PosadA, A. (1921). Estudios sobre el régimen parlamentario de España. Madrid

Pérez Serrano, N. (1976). Tratado de Derecho Político. Madrid. Civitas.

Rico y AMAT, J. (1861). Historia política y parlamentaria de España. Madrid

Ruiz del Castillo, C. (1939). Manual de Derecho Político. Madrid. Reus.

Santamaría de Paredes, V. (1882). Curso de Derecho Político. Madrid. Ricardo Fe.

SÁNCHEZ AgeSta, L. (1964). Historia del constitucionalismo español. Madrid. IEP.

SEvilla ANDrés, D. (1968). Historia política de España. (1808-1967). Madrid. Editora Nacional.

SARrailh, J. (1957). LA España ilustrada de la segunda mitad del siglo XVIII. MéxicoMadrid. Fondo de Cultura Económica.

Tomás Villarroya, J. (1981). Breve historia del constitucionalismo español. Madrid. CEC.

Torres del Moral, A. (1986). Constitucionalismo histórico español. Madrid. Átomo.

\section{Monografías}

Argüelles, A. (1970). La reforma constitucional en Cádiz (Comentado por J. Longares). Madrid. Bitácora.

Comellas, J. L. (1963). El trienio constitucional. Madrid. Rialp.

Cillán Apalategui, A. (1975). Verificación de poderes en España. San Sebastián. Seminario de Estudios Sociales «Marqués de Narros». 
Congreso De los Diputados. (1911). Inviolabilidad e inmunidad Congreso-Senado 1810-1911. Madrid. Sucesores de J. A. García.

- (1916). Incompatibilidades e incapacidades parlamentarias (1810-1910). Madrid. V. Tordesillas.

Flórez Estrada, A. (1973). En defensa de las Cortes. Madrid. Castellote.

Jovellanos, G. «Discurso dirigido a la Sociedad de Amigos del País de Asturias sobre los medios de promover la felicidad de aquel Principado». BAE

MARAVALL, J. L. (1947). Los reglamentos de las Cámaras legislativas y el sistema de comisiones. Madrid. IEP.

MARTínez SOSPEDRA, M. (1974). Incompatibilidades parlamentarias en España (18101936). Valencia. Cosmos.

Murillo Ferrol, F. (1959). «El manifiesto de los persas y los orígenes del liberalismo español» en Homenaje a Nicolás Pérez Serrano. Tomo II. Madrid. Reus.

Pérez-Prendez, J. M. (1974). Cortes de Castilla. Madrid. Ariel.

Pons y Umbert, A. (1910). Prerrogativa del Congreso de los Diputados para el examen de las calidades y legalidades de la elección de sus individuos. Madrid

SANZ Cid, C. (1922). La Constitución de Bayona. Madrid. Reus.

Tomás Villarroya, J. (1968). El sistema político del Estatuto Real (1834-1836). Madrid. IEP.

\section{Revistas, Anuarios, Cursos}

Fernández Almagro, M. (1962). «Del antiguo régimen a las Cortes de Cádiz». REP, núm. 126.

García-Pelayo, M. (1949). «La constitución estamental». REP, núm. 44.

MARTíneZ SOSPEDRA, M. (1974). «Incompatibilidades parlamentarias en España 1810-1836», Cátedra F. Ceriol, Facultad de Derecho, Valencia

Pérez Prendes, J. M. (1962). «Cortes de Castilla y Cortes de Cádiz». REP, núm. 126.

Tomás Villarroya, J. (1964). «La reforma de la Constitución de 1812 en 1836», Revista del Instituto de Ciencias sociales. Barcelona 1964

— (1962). «La Constitución de 1812 en la época del Estatuto Real», REP núm. 126.

\section{Documentación}

Archivo del Congreso de los Diputados, legajos 5 y 7

Diarios de Sesiones de las Cortes Españolas, 1810-1936

Castro, A. (1913). Cortes de Cádiz. Complementos de las sesiones verificadas en la Isla de León y Cádiz. Madrid. Imp. Prudencio Pérez de Velasco.

Castro, C. (1910). Antología de las Cortes de 1820. Madrid. Imp, Prudencio Pérez de Velasco. 
Congreso de los Diputados (1906). Leyes electorales y proyectos de ley. Madrid. Imp. Hijos de J. A. García.

Cortes-Secretaría (1977). Reglamentos (del Congreso de los Diputados y de las Cortes). Madrid

García Nieto, C y otros. (1971). Revolución y reacción (1808.1833). Madrid. Guadiana.

MartíneZ YagüEs, F. (1914). Antología de las Cortes de 1821 a 1823. Encargada por el Sr. Presidente del Congreso de los Diputados. Madrid

Tierno Galván, E. (1968). Leyes políticas fundamentales (1808-1936). Madrid. Tecnos.

Villanueva, J. L. (1820). Apuntes sobre el arresto de los vocales de Cortes ejecutado en mayo de 1814, escritos en la cárcel de la Corona por el diputado Villanueva, uno de los presos. Madrid. Imp. De don Diego García y Campoy.

- (1860). Mi viaje a las Cortes. Diputado en las generales y extraordinarias del reino, instaladas en la isla de León en 24 de septiembre de 1810, impresa por acuerdo de la Comisión de Gobierno interior del Congreso de los Diputados. Madrid. Imprenta Nacional.

- (1964). Actas de las Cortes de Cádiz (selección). Madrid. Taurus.

Title:

THE VERIFICATION OF POWERS IN THE ELABORATION AND IMPLEMENTATION OF THE CONSTITUTION OF 1812

\section{Summary:}

SUMMARY. 1. Introduction. 2. Brief approach to the origin of the parliamentary electoral control. 3. Debate around the competent organ to exert the electoral control on the eve of the Constitution of extraordinary Courts of 1810. 3.1. The conclusions of the Meeting of Ceremonial. 3.2. The communication of the Commission of Cortes. 3.3. Performance of the Regency Council. 3.4. Final considerations. 4. Legal scope of application of the parliamentary electoral control. 4.1 Territorial scope. 4.2. Material scope. 5. Parliamentary procedure of election certificate examination. 5.1. Initial procedure. 5.2. The provisional Regulation of 1810. 5.3. The Regulation of 1813: first regulation of the procedure of verification of powers. The Regulation of 1821 like continuation of the previous one. 6. Parliamentary practice of the verification of powers. 6.1. Applied legal-political criteria in Constituent Cortes of 1810. 6.2. Applied legal-political criteria in Cortes of 1813. 6.3. Applied legal-political criteria in Cortes of 1820. 6.4. Applied legal-political criteria in Cortes of 1822. 7. Foundation and nature of the verification of powers in period 1810-1822. Sum- 
mary. 7.1. Discussion of legitimacies prior to the constitution of Cortes of 1810. 7.2 Parliamentary conception on the verification of powers.

\section{Resumen:}

La verificación de poderes como constatación de que cada uno de los miembros de una Asamblea posee un mandato regular e inatacable, fue competencia exclusiva del Parlamento en todas nuestras Constituciones históricas. Es la Constitución de 1978 —en su artículo 70.2la que judicializa los conflictos de actas electorales, ante el convencimiento de que el Parlamento a lo largo de su historia ha demostrado cumplidamente su incapacidad, como órgano fundamentalmente político, de tomar una decisión judicial imparcial que garantice a las minorías un tratamiento jurídico adecuado.

La verificación de poderes fue, sin embargo, una institución con un profundo sentido histórico. Su crisis es paralela a la superación de las estructuras políticas del Estado liberal, que se vertebran esencialmente en torno a la quiebra de la soberanía parlamentaria y a la subsiguiente concepción del Parlamento como poder constituido sometido a la Norma fundamental como un órgano del Estado. Y es en la etapa de elaboración y vigencia de la Constitución de 1812, en la que surgen los criterios que defienden el control electoral como competencia exclusiva del Parlamento. Por tanto, en este trabajo se aborda, no sólo la regulación establecida en la Constitución de 1812 y la práctica parlamentaria derivada de la misma, sino los momentos anteriores a la reunión de Cortes, en donde se plasma de forma directa el duro enfrentamiento entre los partidarios del Antiguo Régimen y los que defienden la instauración de un nuevo sistema político. La concepción, y posterior decisión, sobre el titular de la verificación de los poderes, y su contenido, va a resultar determinante.

Desde el inicio del régimen constitucional, el Congreso se considera superior a toda norma y a toda crítica: no es un tribunal aplicando la ley, sino un cuerpo político decidiendo, con absoluta libertad, con criterios políticos. Las verificaciones realizadas responden a este pensamiento y, dentro de él, son adecuadas y coherentes: sobre la ley e, incluso, sobre la misma Constitución, hay un organismo superior cuya decisión puede subsanar cualquier elección ilegal o admitir a cualquier electo incapaz, si existe un interés político que lo reclame.

\section{Abstract:}

The verification of credentials, to check that each of the members of Parliament enjoy a proper and unobjectionable mandate, used to be an ex- 
clusive competence of Parliament in all our Constitutions. However, the Constitution of 1978 — in its Article 70(2) — commissions the judicial power to settle the conflicts on electoral mandates. The reason for this is the conviction that Parliament has shown along history its incapacity, as a mainly political institution, to make an impartial judicial decision which guarantees minorities an adequate legal treatment.

The verification of credentials was, however, an institution with a deep historical sense. Its crisis coincides with the overcoming of the political structures of liberal State, which are closely bound to the breakdown of parliamentary sovereignty and to the thus emerging concept of Parliament as a constituted power bound by the fundamental Norm, as an institution of the State. It was during the phase of elaboration and implementation of the Constitution of 1812 when the criteria that settle the electoral control as an exclusive competence of Parliament arose. For this reason, this article deals not only with the regulation established in the Constitution of 1812 and the parliamentary practice which derives from it, but also the previous moments to the meeting of the Cortes, describing the hard confrontation between the supporters of the Old Regime and the people in favour of establishing a new political system. A fundamental factor was the concept and posterior decision on the institution or power entitled to verify the powers and their contents.

From the beginning of the constitutional regime, the Congress regards itself as superior to any norm and to any criticism: it is not a court applying the law, but a political body deciding with an absolute freedom with political criteria. The verifications performed respond to this conception, being accurate and coherent from this point of view: Above the law and, even, over the Constitution, there is a superior body which decision can repair any illegal election or accept any unfit elected person if a political interest demands it.

\section{Palabras clave:}

Parlamentos de 1810, 1813, 1820 y 1822, control electoral parlamentario, aplicación de criterios jurídicos y políticos.

\section{Key words:}

Parliaments of 1810,1813, 1820 and 1822, Parliamentary electoral control. Implementation of legal and political criteria. 
